\title{
KERUKUNAN UMAT BERAGAMA DI KAMPUNG SAWAH KECAMATAN PONDOK MELATI KOTA BEKASI
}

\section{RELIGIOUS HARMONY IN KAMPUNG SAWAH DISTRICT PONDOK MELATI OF BEKASI CITY}

\author{
M Agus Noorbani \\ Balai Litbang Agama Jakarta \\ Jl. Rawa Kuning No. 06 Pulo Gebang Cakung Jakarta Timur 13950 \\ agusbaca@gmail.com
}

Naskah diterima tanggal 29 Juli 2019, Naskah direvisi tanggal 24 Agustus 2019, Naskah disetujui tanggal 3 Oktober 2019

\begin{abstract}
Abstrak
Tulisan ini berusaha menjelaskan apa yang dikemukakan Ashutosh Varshney, bahwa kekerasan komunal merupakan fenomena perkotaan dan jika pun terjadi kekerasan terkonsentrasi secara lokal. Ada wilayah-wilayah yang memiliki tingkat kekerasan tinggi dan ada juga wilayah-wilayah dengan tingkat kekerasan rendah bahkan damai dari berbagai kekerasan dan konflik komunal. Menggunakan rancangan studi kasus kualitatif, penelitian ini berusaha mengetahui mekanisme sosial yang membuat kondisi damai dalam hubungan antar umat beragama di Kampung Sawah tetap terjaga dengan baik. Secara lebih khusus, penelitian ini bertujuan untuk mengetahui tantangan yang dihadapi warga Kampung Sawah dalam menjaga kondisi damai dalam hubungan antar umat beragama. Penelitian ini menemukan bahwa kondisi damai dalam hubungan antar umat beragama di Kampung Sawah yang terjaga hingga kini merupakan hasil dari aktivisme yang sudah berlangsung sejak lama, bahkan sejak awal Kampung Sawah dibangun. Peran faktor ikatan kekerabatan, tokoh masyarakat dan agama, serta modal sosial yang ada di Kampung Sawah secara berkelindan membuat Kampung Sawah mampu menjaga kondisi damai hingga saat ini. Tantangan yang dihadapi warga Kampung Sawah dalam menjaga kondisi damai dalam hubungan antar umat beragama saat ini setidaknya mencakup dua hal; terjangan arus informasi melalui media sosial dan tingginya laju pertumbuhan penduduk pendatang yang terkotak-kotak dalam blok-blok perumahan eksklusif.
\end{abstract}

Kata Kunci: Kampung Sawah, kerukunan, modal sosial, ikatan kekerabatan

\begin{abstract}
This article tries to explain what was Ashutosh Varshney stated that communal violence is a rural phenomenon and if the violence does occur it will be concentrated locally. There are several areas that have high rate of violence and there are other areas with low rate of violence and even devoid of communal violence and conflicts. Using qualitative case study design, this research tries to know the social mechanism that creates peace in the inter religion relation in Kampung Sawah to be wellmaintained. This research especially aims to know the challenges faced by the people of Kampung Sawah in keeping peaceful condition in inter-religion relation. This research finds that peace among inter-religion relation in Kampung sawah has been maintained up to the present is the result of activities which have been conducted since a long time ago, even since Kampung Sawah area was first built. The intertwined of kinship ties, society and religious figures, and the social capital existing in Kampung Sawah have a main role in maintained the peaceful condition unto present. The challenges to maintaining peaces among religious communities at the present encompasses two kinds; the fast penetration of information through social media and the high rate of population growth of migrants who are boxed in exclusive housing blocks.
\end{abstract}

Keywords: Kampung Sawah, harmony, social capital, kinship ties 


\section{PENDAHULUAN}

$\mathrm{T}$ Julisan ini menjelaskan apa yang dikemukakan Ashutosh Varshney, (2009) berdasarkan hasil kajiannya selama tujuh tahun terhadap konflik komunal di India, bahwa kekerasan komunal merupakan fenomena perkotaan dan jika pun terjadi kekerasan terkonsentrasi secara lokal. Ada wilayah-wilayah yang memiliki tingkat kekerasan tinggi namun ada juga wilayahwilayah dengan tingkat kekerasan rendah bahkan damai dari berbagai kekerasan dan konflik komunal. Membandingkan temuan Varshney di India dengan kondisi di Indonesia, akan terlihat pola persebaran konflik yang sama.

Kajian Varshney, Panggabean, dan Tadjoedin (2004) mengenai pola persebaran kekerasan kolektif di Indonesia berdasarkan pemberitaan media massa sepanjang 19902003 menemukan bahwa kekerasan kolektif terbanyak terjadi di empat belas (14) provinsi di Indonesia. Provinsi seperti Jawa Barat, Jawa Timur, dan Jawa Tengah menjadi penyumbang insiden kekerasan kolektif terbesar dari keempat belas propinsi lain dalam kurun masa tersebut. Di ketiga provinsi tersebut terjadi 2.032 insiden kekerasan kolektif atau mencapai $48 \%$ dari 4.270 total insiden kekerasan di seluruh Indonesia. Meski menyumbang insiden kekerasan kolektif tertinggi, namun jumlah korban jiwa meninggal terbesar terdapat di Provinsi Maluku Utara dan Provinsi Maluku yang mencapai 4.840 jiwa atau $43 \%$ dari total korban meninggal dunia dari seluruh insiden konflik kekerasan di Indonesia sepanjang 1990-2003. Padahal, kedua wilayah ini hanya menyumbang 404 insiden konflik kekerasan dalam kurun masa tersebut.

Kajian dengan metode serupa mengenai insiden konflik keagamaan dilakukan oleh Panggabean, Alam, dan Fauzi (2010). Persebaran konflik keagamaan sepanjang 1990-2008 berdasarkan pemberitaan di media massa menemukan bahwa daerah-daerah perkotaan dengan tingkat penduduk yang padat menjadi daerah dengan tingkat insiden konflik keagamaan tertinggi dibandingkan wilayah lain. Propinsi seperti DKI Jakarta dan Jawa Barat, yang merupakan dua propinsi dengan kepadatan penduduk tertinggi di Indonesia dan jumlah wilayah perkotaan terbanyak, menjadi penyumbang terbanyak insiden konflik keagamaan dibanding propinsi lain (410 insiden konflik keagamaan dari 832 insiden konflik). Dalam kategori konflik yang berujung pada kekerasan, wilayah persebaran hanya terdapat di 20 provinsi. Provinsi Jawa Barat, DKI Jakarta, Sulawesi Tengah, Maluku, dan Jawa Timur menjadi penyumbang tertinggi insiden konflik keagamaan yang berujung pada kekerasan.

Kajian-kajian lain menunjukkan bahwa insiden konflik komunal di Indonesia, yang bahkan hingga berujung kekerasan, kerap terjadi di wilayah-wilayah dengan kategori perkotaan dengan kepadatan penduduk tinggi dan luas wilayah yang sangat terbatas. Laporan tahunan yang dikeluarkan Wahid Foundation, (2016) Komisi Nasional (Komnas) Hak Asasi Manusia (HAM) Indonesia, (2016) dan SETARA Institute (2018) misalnya, masih menempatkan DKI Jakarta dan Jawa Barat sebagai wilayah dengan insiden konflik komunal tertinggi. Jika pada akhir 1990an hingga awal tahun 2000an persebaran insiden konflik komunal tidak saja terjadi di Indonesia bagian Barat, Pulau Jawa khususnya, namun juga hingga wilayah Indonesia Timur, Kalimantan, Maluku dan Sulawesi, maka dalam sepuluh tahun terakhir persebaran konflik hanya terkonsentrasi di Indonesia bagian Barat, khususnya di Pulau Jawa. Meski demikian, seperti dihipotesiskan oleh Varshney (2009), persebaran insiden konflik ini terjadi pada skala lokal.

Persebaran konflik komunal di Jawa Barat saja, terutama terkait insiden konflik keagamaan, terkonsentrasi pada wilayahwilayah tertentu. Wilayah-wilayah dengan karakteristik perkotaan, seperti Bogor dan Bekasi (Bagir, Ahnaf, Tahun, dan Asyhari, 2013; HRW, 2013; Wahid Foundation, 2016) menjadi wilayah dengan insiden konflik tertinggi di Jawa Barat. Patut dipertanyakan mengapa insiden konflik komunal cenderung terjadi di wilayah-wilayah dengan karakteristik perkotaan, luas wilayah secara geografis kecil dan dengan kepadatan penduduk tinggi, dan sedikit sekali terjadi di 
wilayah-wilayah dengan karakteristik pedesaan, wilayah yang secara geografis luas dan tingkat kepadatan penduduk rendah? (Bandingkan dengan Varshney, 2009)

Penelitian ini memfokuskan kajian pada kondisi-kondisi damai dan rukun yang terjadi di sebuah wilayah. Meski masih terjadi insiden-insiden konflik komunal terutama konflik bernuansa keagamaan di Indonesia, namun frekuensinya cenderung menurun dalam beberapa tahun belakangan. (SETARA Institute, 2017) Berbagai inisiatif untuk meningkatkan kerukunan dan perdamaian antar umat beragama telah banyak dilakukan, baik oleh pemerintah maupun masyarakat. Dalam aspek regulasi, berbagai peraturan dikeluarkan pemerintah (melalui Kementerian Agama, Kementerian Dalam Negeri, dan institusi lain) untuk menjadi pegangan berbagai pihak. Meskipun, tidak sedikit yang menganggap bahwa berbagai peraturan yang dibuat pemerintah justru makin memperuncing kondisi kerukunan umat beragama di Indonesia. (lihat misalnya Bagir dkk., 2013; Halili \& Naipospos, 2015; HRW, 2013)

Kementerian Agama, melalui Badan Litbang dan Diklat, juga telah mengeluarkan Buku Pedoman Penanganan Aliran dan Gerakan Keagamaan Bermasalah di Indonesia. (2014) Buku ini menjadi babak baru dalam memandang aliran dan gerakan keagamaan di Indonesia. Jika pada tahun-tahun sebelum penerbitan buku pedoman ini kelompokkelompok keagamaan yang tidak sejalan dengan pemahaman arus utama dianggap sebagai aliran dan gerakan yang menyimpang, maka melalui penerbitan buku ini kelompokkelompok tersebut tidak lagi disebut sebagai menyimpang melainkan dikategorikan bermasalah dengan indikator-indikator dan tipologi yang dijabarkan dalam buku ini. Perubahan istilah memberi paradigma baru bagi para aktor terdepan Kementerian Agama, yakni para penyuluh, dalam memberikan pemahaman kepada masyarakat mengenai kelompok-kelompok keagamaan ini.

Selain melalui upaya dengan dikeluarkannya berbagai regulasi dan buku pedoman, upaya lain yang dilakukan pemerintah dan masyarakat, melalui berbagai lembaga swadaya masyarakat (LSM), adalah menginisiasi daerah-daerah rukun dan damai di berbagai wilayah di Indonesia. Wahid Foundation menginisiasi pembentukan kampung damai di tiga provinsi, yakni Jawa Barat, Jawa Tengah, dan Jawa Timur. Program ini dibangun atas landasan bahwa perdamaian dan kerukunan dapat terbangun jika masyarakat mampu mandiri dan kuat secara ekonomi (Yulianto, 2017). Pemerintah melalui Pusat Kerukunan Umat Beragama (PKUB) Kementerian Agama (2017) juga membuat program Desa Sadar Kerukunan yang dibentuk di beberapa wilayah, seperti Lunang Silaut di Kabupaten Pasaman Barat Provinsi Sumatera Barat, Lingga di Provinsi Kepulauan Riau dan berbagai desa di provinsi lainnya. Hanya saja, pembentukan desa sadar kerukunan ini tidak memiliki landasan argumen yang jelas.

Sebelum berbagai lembaga, baik pemerintah maupun masyarakat, menginisiasi program kampung atau desa sadar kerukunan di atas, di berbagai daerah di Indonesia sudah terbentuk berbagai wilayah, baik kampung maupun desa, yang mampu menjaga kerukunan antar umat beragama. Kampung Sawah, yang berlokasi di Kecamatan Pondok Melati, Kota Bekasi misalnya, merupakan salah satu wilayah dengan kondisi toleransi yang sudah terjaga sejak lama. Meski terletak di wilayah Jawa Barat, penduduk asli Kampung Sawah adalah suku Betawi. Kampung Sawah seolah menjadi anomali dari kondisi Kota Bekasi yang kerap disorot dalam berbagai laporan kebebasan beragama dan berkeyakinan karena menjadi salah satu kota paling tidak toleran, meskipun dalam beberapa tahun belakang kondisi toleransi di Kota ini meningkat. (SETARA Institute, 2017) Di Kampung Sawah ini terlihat bentuk toleransi antar umat beragama, di mana umat Islam, Kristiani, dan berbagai umat agama lain hidup berdampingan dan saling menghargai satu sama lain. (Firdaus, 2016; Wardah, 2017)

Penelitian ini memfokuskan kajian pada wilayah dengan keragaman keyakinan yang bervariasi namun mampu memelihara kerukunan umat beragama. Secara khusus, penelitian ini mengkaji berbagai tantangan yang dihadapi masyarakat Kampung Sawah sebagai sebuah daerah yang rukun dan damai. Sebagai sebuah wilayah yang sangat strategis, 
karena terletak di perbatasan provinsi DKI Jakarta dan Jawa Barat, Kampung Sawah tentu menjadi magnet bagi banyak pendatang untuk mencari kediaman yang nyaman dan terjangkau.

Pertanyaan utama penelitian ini adalah; Bagaimana mekanisme sosial yang membuat kondisi damai dalam hubungan antar umat beragama di Kampung Sawah tetap terjaga?, dan Apa tantangan yang dihadapi warga Kampung Sawah dalam menjaga kondisi damai dalam hubungan antar umat beragama?

Penelitian ini bertujuan untuk mengetahui mekanisme sosial yang membuat kondisi damai dalam hubungan antar umat beragama di Kampung Sawah tetap terjaga dengan baik. Secara lebih khusus, penelitian ini bertujuan untuk mengetahui tantangan yang dihadapi warga Kampung Sawah dalam menjaga kondisi damai dalam hubungan antar umat beragama. Signifikansi penelitian ini dapat meminjam apa yang dikemukakan Varshney (2009), bahwa hingga kita mengkaji tentang kedamaian antar etnis, kita tidak akan memiliki teori yang cukup baik untuk bisa menjelaskan konflik antar etnis. Hasil penelitian ini diharapkan dapat memberikan kontribusi akademik dalam memahami aspekaspek terpeliharanya kerukunan antar umat beragama di sebuah wilayah. Hasil penelitian ini diharapkan juga dapat memberikan kontribusi bagi kebijakan pemeliharaan dan peningkatan kerukunan antar umat beragama di Indonesia.

Hayat (2012) menawarkan tiga pendekatan, yang sifatnya berlapis (multilayers conception), dalam meningkatkan harmonisasi kehidupan beragama di Indonesia. Pertama adalah pembangunan modal sosial (social capital) sebagai landasan untuk mengatasi faktor endogen dan relasional yang kerap menjadi faktor dalam konflik antar umat beragama di Indonesia. Faktor endogen dijelaskan sebagai faktor teologis dan ritual keagamaan, sementara faktor relasional adalah faktor-faktor yang berkaitan dengan hubungan antar umat beragama seperti pendirian rumah ibadah, penyiaran agama, dan penodaan agama. Kedua berupa pengembangan kebangsaan berwawasan multikultural bagi setiap warga negara dalam membangun Indonesia di tengah keragaman dan kemajemukan penduduk. Ketiga pembangunan sosial, ekonomi, dan politik dengan pendekatan kebangsaan yang berwawasan multikultural untuk mengatasi faktor eksogen. Faktor eksogen yang dimaksud adalah faktor-faktor dari luar seperti pengaruh globalisasi, ketimpangan dunia, dan permasalahan hak asasi manusia (HAM).

Berbagai kajian mengenai kerukunan yang pernah dilakukan menunjukkan bahwa tiga pendekatan yang dikemukan Hayat di atas menemukan nilai pentingnya. Kajian yang dilakukan Mahadi (2013) terhadap kerukunan antar umat beragama di Desa Talang Benuang Kabupaten Seluma, Provinsi Bengkulu misalnya menemukan bahwa kerukunan yang terjalin di desa ini, antara penduduk asli yang beragama Islam dengan penduduk pendatang (para transmigran) yang beragama Hindu, Kristen, dan lainnya terjadi karena interaksi melalui berbagai kegiatan keseharian seperti gotong royong, kelompok tani, kredit simpan pinjam, dan lainnya. Interaksi harmonis ini terjadi karena faktor-faktor berupa kesadaran masyarakat mengenai kerukunan yang ditumbuhkan sejak dini, wawasan kebangsaan dalam kehidupan bermasyarakat sehari-hari, dan adanya ikatan kekerabatan akibat pernikahan.

Temuan yang sama dihasilkan Salahudin (2008) di Desa Klepu Kabupaten Ponorogo, Provinsi Jawa Timur. Masyarakat Desa Klepu mampu menjaga keharmonisan antar warga yang memiliki keyakinan keagamaan yang berbeda-beda, di mana penduduknya beragama Islam dan Katholik, melalui aktivitas harian seperti gotong royong, intensitas pertemuan antar warga yang cukup tinggi, dan mendahulukan kepentingan warga tanpa melihat identitas keagamaan. Selain kedua hal tersebut, keharmonisan antar umat beragama di Desa Klepo terjadi karena adanya jalinan kekerabatan yang tercipta dari pernikahan di antara warga. Selain aspekaspek ini, keharmonisan antar warga di desa ini terjadi dengan masih dirawatnya tradisi slametan yang dijalankan oleh setiap warga, baik yang beragama Islam maupun Katholik, pada setiap hajatan pribadi. 
Berdasarkan kajian-kajian mengenai peningkatan kerukunan umat beragama di atas terlihat bahwa kerukunan antar umat beragama dapat tercipta dengan dukungan faktor intensitas pertemuan yang tinggi di antara warga dalam kegiatan keseharian, terwujudnya saling percaya antar warga akibat intensitas pertemuan dalam aktivitas keseharian, dan ikatan kekerabatan yang tercipta dari pernikahan di antara sesama warga, baik dengan sesama agama maupun perkawinan antar agama. Hal tersebut dalam kajian sosiologi dikenal sebagai modal sosial.

Konsep modal sosial pertama kali diperkenalkan oleh Lyda Judson Hanifan, seorang supervisi sekolah di Charleston, Amerika Serikat. (Syahra, 2003; Taormina, Kuok, \& Wei, 2012) Hanifan (1916) menyatakan bahwa yang ia maksudkan sebagai modal sosial bukanlah modal dalam pengertian harta kekayaan seperti rumah, uang tunai dan berbagai harta yang nampak lainnya. Modal sosial yang ia maksudkan adalah halhal yang terwujud dalam kehidupan sehari-hari masyarakat seperti simpati, berbuat baik, kebersahabatan, kerjasama antar warga yang membentuk sebuak kelompok masyarakat. Istilah ini kemudian dikembangkan lebih jauh oleh banyak sosiolog, seperti Pierre Bordieu, James Coleman, Robert Puttnam, dan lainnya. (Syahra, 2003)

Putnam sendiri mendefinisikan modal sosial sebagai berbagai ciri organisasi sosial seperti jaringan, norma, dna kepercayaan yang memudahkan anggota organisasi untuk koordinasi dan bekerjasama demi mendapatkan manfaat bersama. (Syahra, 2003) Putnam menyatakan bahwa modal sosial yang mampu mencegah berbagai permasalahan sosial. Putnam mensinyalir bahwa terjadinya banyak permasalahan sosial di Amerika pada dekade 80-90an akibat hilangnya modal sosial dalam masyarakat Amerika, yang mulai terjadi 30 tahun sebelum dekade tersebut. Menurut Putnam, modal sosial memiliki tiga komponen; ikatan moral dan norma yang terbentuk dalam masyarakat, nilai-nilai sosial terutama rasa saling percaya, dan jejaring sosial terutama keterlibatan individu secara sukarela dalam kelompokkelompok masyarakat yang bersifat formal.
Putnam menyatakan bahwa sebuah negara atau wilayah akan memiliki sistem ekonomi dan politik yang baik dan warganya sejahtera, maka ini merupakan keberhasilan wilayah tersebut memanfaatkan modal sosial yang mereka punya. (Siisiäinen, 2000)

Putnam, pada periode berikutnya, menjelaskan apa yang disebut sebagai modal sosial yang menjembatani (bridge) dan modal sosial yang mengikat (bond). Modal sosial yang menjembatani adalah ikatan antar warga yang terdiri dari berbagai kelompok masyarakat, baik etnis maupun agama, yang tercipta atas dasar saling percaya di antara anggotanya. Sedangkan modal sosial yang mengikat adalah ikatan antar warga yang terdiri dari satu kelompok masyarakat, baik etnis ataupun agama. Bentuk modal sosial pertama lebih inklusif, sedangkan bentuk modal sosial yang kedua lebih eksklusif karena cenderung memperkuat identitas kelompok sejenis. (Siisiäinen, 2000; bandingkan dengan Varshney, 2009) Varshney (2009) menyebut kelompok pertama sebagai kelompok interkomunal sedangkan yang kedua merupakan kelompok intrakomunal.

Konsep Putnam ini kemudian dikembangkan lebih lanjut oleh Varshney. (2001; 2009) Berdasarkan hasil kajian mengenai konflik antara pemeluk Hindu dan Islam di India, ia mengemukakan apa yang disebut sebagai ikatan kewargaan asosiasional dan ikatan kewargaan keseharian. Ikatan kewargaan asosiasional merupakan ikatan kewargaan yang mengumpulkan beragam kelompok masyarakat, baik dari segi etnis, agama, maupun identitas komunal lainnya. Contoh ikatan kewargaan ini adalah organisasi profesi, klub olahraga, serikat buruh, klub film. Sementara ikatan kewargaan keseharian adalah ikatan yang mempertemukan berbagai kelompok warga, dari beragam etnis, agama, dan identitas komunal lainnya dalam aktivitas keseharian seperti saling kunjung saat hari besar agama, gotong royong, makan malam bersama.

Varshney menyatakan bahwa kedua bentuk ikatan ini penting dalam meningkatkan kondisi damai sebuah daerah. Menurutnya, di kota-kota di India yang dilanda kerusuhan dan kekerasan komunal, religiusitas warganya 
meningkat secara nyata, bukan saja di kotakota lain yang damai dari konflik komunal. Ikatan kewargaan, baik asosioasional maupun keseharian, mampu memfasilitasi atau mencegah terjadinya kerusuhan. Meski kedua ikatan ini mampu mencegah sebuah wilayah dilanda kerusuhan antar etnik, namun Varshney (2009) berkeyakinan, berdasarkan bukti-bukti lapangan yang dimilikinya, bahwa ikatan asosiasional yang lebih mampu mencegah kerusuhan komunal dibanding ikatan keseharian.

Bain dan Hicks (dalam Syahra, 2003) menyatakan bahwa terdapat dua dimensi sebagai kerangka konseptual untuk dapat mengukur modal sosial. Dimensi pertama adalah dimensi kognitif atau dimensi kultural seperti nilai-nilai, sikap, dan keyakinan yang memengaruhi kepercayaan, solidaritas, dan resiprositas yang mampu menciptakan kerjasama dalam masyarakat demi mencapai tujuan bersama. Setiap kelompok masyarakat memiliki kadar dimensi kultural yang berbeda. Ada yang kaya akan nilai-nilai solidaritas dan kerjasama dalam kelompok sendiri namun tidak cakap berhubungan dengan kelompok lain, ada kelompok masyarakat yang memiliki kekayaan budaya yang mampu mencipatakan hubungan harmonis antar anggota kelompoknya dan dengan kelompok lain.

Dimensi kedua, menurut Bain dan Hicks (dalam Syahra, 2003) adalah dimensi struktural yang merupakan susunan, ruang lingkup organisasi, dan lembaga-lembaga masyarakat pada tingkat lokal yang mewadahi dan mendorong terjadinya kegiatan-kegiatan kolektif yang bermanfaat bagi setiap anggota masyarakat. Dimensi ini penting karena mampu mewadahi berbagai anggota kelompok masyarakat dengan berbagai latar belakang nilai, norma, dan budaya karena tujuan akhir dari dimensi struktural ini adalah kesejahteraan setiap anggota kelompok masyarakat. Dimensi struktural ini dapat terwujud dalam bentuk kelompok-kelompok organisasi hobi, koperasi, dan berbagai organisasi lain.

\section{METODE PENELITIAN}

Penelitian ini merupakan kajian kualitatif dengan pendekatan studi kasus.
Pengumpulan data mengkombinasikan teknik wawancara dan observasi lapangan. Wawancara dilakukan dengan para tokoh masyarakat, tokoh agama, aparatur pemerintahan setempat, dan masyarakat. Observasi dilakukan terhadap aktivitas keseharian penduduk, kondisi dan situasi Kampung Sawah, dan lokasi rumah ibadah bagi warga setempat. Data hasil wawancara dan observasi dikombinasikan dengan data pendukung seperti data kependudukan tingkat desa/kelurahan.

Penelitian dilakukan selama dua puluh lima hari dalam dua tahapan, yaitu penjajakan lapangan dan pengumpulan data lapangan di Kampung Sawah, Kecamatan Pondok Melati Kota Bekasi. Secara geografis, Kampung Sawah terletak di Kota Bekasi, yang termasuk wilayah perkotaan dengan tingkat intoleransi yang tinggi. Meski menjadi bagian dari Provinsi Jawa Barat, namun penduduk Kampung Sawah tidak identik dengan suku dan bahasa Sunda, yang identik dengan Provinsi Jawa Barat. Wilayah ini menjadi wilayah tepian sekaligus penghubung dari dua provinsi besar; DKI Jakarta dan Jawa Barat. Karenanya, penduduk asli Kampung Sawah mayoritas merupakan penduduk yang bersuku dan berbahasa Betawi dan sebagian kecil bersuku dan berbahasa Sunda (bandingkan dengan Jamaludin, 2015). Penjajakan lapangan berlangsung selama lima hari dengan tujuan melakukan observasi awal lokasi penelitian dan mengumpulkan data pendukung seperti demografi penduduk, dan mengidentifikasi informan-informan kunci. Pengumpulan data lapangan dilakukan selama delapan belas hari untuk mengumpulkan data utama penelitian melalui wawancara dengan informan kunci dan observasi terhadap wilayah sasaran penelitian.

\section{PEMBAHASAN}

\section{Gambaran Umum Kampung Sawah}

Kampung Sawah merupakan wilayah yang termasuk ke dalam Kecamatan Pondok Melati, Kota Bekasi. Wilayah ini mencakup tiga kelurahan, yaitu Kelurahan Jati Murni, Kelurahan Jati Melati, dan Kelurahan Jati Warna dengan luas mencapai sekitar 8 
kilometer persegi $\left(\mathrm{km}^{2}\right)$. Pak Jacobus Napiun, salah seorang tokoh masyarakat di Kampung Sawah, mengatakan bahwa dalam ingatannya secara geografis Kampung Sawah berakhir di Pasar Kecapi di bagian Utara, berbatasan dengan daerah Pabuaran di Selatan, berbatasan dengan Kali Cakung di Timur, dan berbatasan dengan Kali Sunter di Barat. Titik pusat Kampung Sawah terletak pada tempat di mana saat ini berdiri tiga rumah ibadah utama; Masjid Al-Jauhar, Gereja Kristen Pasundan (GKP) Kampung Sawah, dan Gereja Katolik Santo (St.) Servatius. Dalam pandangan warga, ketiga rumah ibadah ini menjadi penanda wilayah Kampung Sawah. Di lokasi ini pula terletak batas wilayah Kelurahan Jati Murni dan Jati Melati.

Wilayah ini terkenal dengan sebutan Kampung Sawah karena pada awal terbentuknya merupakan blok perkampungan yang diselingi persawahan. Kampung Sawah pada awalnya merupakan areal hutan yang dibuka untuk markas para prajurit Kesultanan Mataram yang hendak menyerang Batavia. Dalam perkembangannya, wilayah ini kemudian menjadi pemukiman para prajurit yang tidak kembali seusai penyerangan. Seiring dengan pertambahan jumlah penduduk, wilayah ini kemudian semakin meluas. Persawahan yang dibuka merupakan areal yang dibuat penduduk dan merupakan sawah tadah hujan bukan persawahan pengairan. Akibat pembukaan wilayah untuk persawahan, kontur Kampung Sawah menjadi berbukit-bukit, di mana daerah yang tinggi merupakan perkampungan dan daerah yang rendah merupakan persawahan.

Meski secara geografis Kampung Sawah mencakup tiga kelurahan, seperti tersebut di atas, namun secara identitas saat ini wilayahnya mulai menyempit sebagai akibat dari perkembangan jumlah penduduk dan hunian. Banyak warga, terutama para pendatang baru yang tinggal setelah tahun 2000an dan, yang bermukim dalam radius lebih dari $3 \mathrm{~km}$ dari titik pusat Kampung Sawah tidak lagi mendaku sebagai warga Kampung Sawah. Pak Jacobus Napiun menyatakan, para penduduk baru ini senang menyebut diri mereka sebagai penduduk perumahan yang mereka huni. Penduduk yang mendaku sebagai warga Kampung Sawah kini terkonsentrasi di dua kelurahan, yaitu Kelurahan Jati Murni dan Kelurahan Jati Melati.

Perubahan komposisi penduduk di Kampung Sawah disinyalir mulai terjadi pada tahun 1970an usai Markas Besar (Mabes) Tentara Nasional Indonesia (TNI) dibangun di Cilangkap. Seperti dikemukakan Pak Mihardja, juga salah seorang sesepuh di Kampung Sawah, banyak warga Kampung Sawah menjual aset mereka, berupa tanah maupun sawah, karena mendapat kabar bahwa penduduk di wilayah Cilangkap mendapat untung dari hasil menjual tanah dan sawah mereka dalam satuan meter persegi. Pada masa sebelumnya, warga Kampung Sawah menjual tanah atau sawah mereka dalam satuan yang tidak pasti. Banyaknya warga yang menjual aset ini kepada warga luar Kampung Sawah yang kemudian diikuti dengan masuknya warga dari luar Kampung Sawah.

Perubahan komposisi penduduk asli dan pendatang menjadi semakin tinggi saat pengaspalan Jalan Raya Kampung Sawah selesai pada tahun 1994-1995 yang mempermudah akses dari dan menuju Kampung Sawah. Meski demikian, hingga tahun 2000an komposisi penduduk di Kampung Sawah masih didominasi penduduk asli. Baru pada tahun 2007 atau setelah beroperasinya ruas Jalan Tol Jakarta Outer Ring Road (JORR) E1 Seksi 3 yang terentang dari Hankam hingga Jatiasih, banyak pendatang mulai bermukim di Kampung Sawah. Banyak pemukiman baru yang berbentuk komplek perumahan atau cluster dibangun. Menurut Pak Mihardja yang membuat banyak pendatang tertarik untuk tinggal di banyak pemukiman di Kampung Sawah di antaranya adalah kemudahan akses jalan, transportasi, dan berbagai fasilitas lainnya, seperti ketersediaan rumah ibadah yang beragam, dan kondisi Kampung Sawah yang relatif aman sehingga nyaman sebagai wilayah hunian.

Komposisi penduduk Kampung Sawah, yang terkonsentrasi di kedua kelurahan seperti tersebut di atas, saat ini terdiri dari berbagai suku dan agama. Di Kampung Sawah hidup berdampingan penduduk dari suku 
Betawi, Jawa, Flores, Ambon, Batak, Nias, dan lainnya. Mereka memeluk agama Islam, Kristen, Katholik, Hindu, dan Budha. Jumlah penduduk Kampung Sawah yang berada di dua kelurahan utama, seperti terlihat pada Tabel 1, berjumlah 39.620 jiwa yang terdiri dari 20.100 orang laki-laki dan 19.520 orang perempuan. Jumlah kepala keluarga (KK) yang menetap di Kampung Sawah tercatat sebanyak 10.751 KK. Meski penduduk terbanyak terdapat di Kelurahan Jati Murni dibandingkan dengan penduduk yang bertempat tinggal di Kelurahan Jati Melati, namun jumlah Rukun Tetangga (RT) dan Rukun Warga (RW) terbanyak terdapat di Kelurahan Jati Melati. Di Kelurahan Jati Melati terdapat 91 RT dan 15 RW, sementara di Kelurahan Jati Murni terdapat $59 \mathrm{RT}$ dan $8 \mathrm{RW}$.

Penduduk Kampung Sawah mayoritas memeluk agama Islam, dengan jumlah pemeluk sebanyak 25.963 jiwa. Pemeluk agama Katholik yang tinggal di Kampung Sawah sebanyak 8.828 jiwa, atau terbanyak kedua, diikuti oleh agama Kristen yang dipeluk oleh 3.952 jiwa. Penduduk yang memeluk agama Hindu dan Budha, masingmasing, sebanyak 319 jiwa dan 558 jiwa. Rumah ibadah yang terdapat di Kampung Sawah terdiri dari 33 masjid, 1 gereja Katholik, dan 16 gereja Kristen. Bagi umat Hindu, meski tidak terdapat pura di Kampung Sawah, namun terdapat Balai Banjar Hitakarma di Kelurahan Jati Melati. Balai banjar ini adalah semacam lembaga pendidikan yang diperuntukkan bagi para pelajar di Kampung Sawah dan sekitarnya untuk memperdalam ilmu Agama Hindu yang dilakukan setiap hari Minggu.

Jenis pekerjaan yang dijalani penduduk Kampung Sawah sangat beragam. Sebagian besar bekerja di sektor formal sebagai pegawai, baik di instansi swasta maupun milik pemerintah. Namun, tidak sedikit juga yang bekerja sebagai pedagang. Dengan menyusutnya lahan kosong yang dipergunakan sebagai lahan pertanian ataupun peternakan, maka semakin berkurang mereka yang bekerja dalam bidang pertanian maupun peternakan. Hingga tahun 1980an komposisinya adalah sebaliknya, banyak warga Kampung Sawah yang bekerja pada sektor pertanian, peternakan, dan perdagangan. Penduduknya banyak menjual hasil tani dan ladang mereka, seperti beras, sayur-mayur, dan bebuahan di berbagai pasar di wilayah Jakarta Timur, Jakarta Pusat, hingga Jakarta Selatan. Hanya sedikit yang bekerja pada sektor formal sebagai pegawai. Meski demikian, sejak jaman kolonial, penduduk Kampung Sawah terkenal sudah memiliki pekerjaan lebih baik daripada penduduk lain di Kota Bekasi. Tidak sedikit dari penduduk Kampung Sawah yang bekerja sebagai tenaga pendidik, tenaga kesehatan, dan administratur pada pemerintahan kolonial.

Hal tersebut tidak terlepas dari tingkat pendidikan yang mampu ditempuh oleh penduduk Kampung Sawah. Menurut Pak Mihardja dan Pak Budiman, penduduk Kampung Sawah sudah mengenal kemampuan membaca dan menulis huruf latin sejak awal abad ke-19. Artinya, setidaknya jika dibandingkan dengan penduduk lain di Kota Bekasi, penduduk Kampung Sawah saat itu sudah lebih maju dalam tingkat pendidikan modern. Perkembangan lembaga pendidikan modern di Kampung Sawah seiring dengan masuknya agama Kristen di Kampung Sawah. Sekolah Dasar Negeri (SDN) 01 dan 06 Jati Murni yang ada saat ini, menurut Pak Budiman yang juga mantan Kepala SDN 01 Jati Murni, cikal-bakalnya adalah sekolah yang berlokasi di Gereja Kristen Pasundan (GKP) Kampung Sawah, yang mulai disemai pendiriannya pada awal abad 19.

Penduduk Kampung Sawah, menurut Pak Mihardja, pada awalnya merupakan bala tentara Kesultanan Mataram yang hendak menyerang markas Vereenigde Oostindische Compagnie (VOC) di Batavia (Jakarta saat ini). Dalam penuturan Pak Mihardja, seperti yang ia dapat dari cerita orang-orang tua yang ia temui, bala tentara Kesultanan Mataram ini terdiri dari berbagai suku yang ada tersebar di berbagai daerah di Nusantara. Mereka merupakan pasukan yang ditugaskan untuk mengintai Batavia dan memberi informasi kepada Kesultanan Mataram mengenai kondisi pasukan VOC. Sebagai pasukan pengintai, mereka kemudian membangun markas di tengah-tengah hutan yang terletak di pinggiran Batavia, daerah yang kini menjadi wilayah 
Kampung Sawah. Serangan Kesultanan Mataram terhadap VOC di Batavia dalam dua kali kesempatan di tahun 1628 dan 1629 berujung kegagalan yang membuat pasukan Kesultanan Mataram mundur meninggalkan Batavia. Pasukan pengintai yang bermarkas di Kampung Sawah ini tidak ikut serta (tidak jelas benar, apakah pasukan ini ditinggal atau tertinggal) dengan pasukan lain yang meninggalkan Batavia.

Komunitas yang berasal dari berbagai daerah ini kemudian membentuk masyarakat Kampung Sawah. Asal-usul penduduk yang beragam ini yang membuat Kampung Sawah menjadi daerah yang sangat terbuka dan toleran terhadap nilai-nilai yang berbeda. Dari berbagai perbedaan ini, kemudian terbentuk sebuah komunitas masyarakat yang memiliki kebudayaan baru dan khas. Ciri khas ini tercermin dalam bentuk bahasa dan berbagai tradisi yang berkembang di Kampung Sawah.

Masyarakat asli Kampung Sawah mengidentifikasi diri mereka sebagai suku Betawi. Hal ini dapat terlihat dari bahasa dan tradisi yang berkembang di daerah tersebut. Meski mengidentikkan diri sebagai suku Betawi, bahasa yang mereka gunakan bukan Bahasa Betawi seperti yang digunakan oleh suku Betawi di wilayah Jakarta. Perbedaan terletak pada bunyi "e" dalam setiap kata berakhiran "a" pada Bahasa Betawi yang digunakan oleh suku Betawi yang tinggal di Jakarta, namun tidak ditemukan dalam Bahasa Betawi yang digunakan oleh masyarakat Betawi yang tinggal di Kampung Sawah. Jika warga Betawi di Jakarta mengatakan "kate", "kaye", atau "kenape" maka masyarakat Betawi di Kampung Sawah mengatakan katakata tersebut dengan "kata", "kaya", dan "kenapa".

Sebagai contoh dapat dilihat dalam sebuah cerita Jaga Timbul yang menggambarkan aktivitas keseharian warga Kampung Sawah berikut;

Biar kata diubek rame-rame, nggak semиa ikan bisa ketangkep. Apalagi ikan yang rada kuat ama lumpur, kaya lele, sili, kocolan, betik/betok. Rada siangan dikit, orang-orang udah pada pulang. Matahari masih bersinar terang, panasnya bikin aer di sawah yang baru diubek jadi rada anget. Angetnya terus nyampe ke lumpur. Nah dalam keadaan kaya gini, biasanya ikan pada nongol kepermukaan buat nyari kesegeran. Inilah saatnya jaga timbul.

Beberapa orang yang masih penasaran, nggunain kesempetan ini. Mereka pada nagog di galengan, ato juga pada berendem (palingpaling dalemnya sedengkul) di tengah sawah nungguin ikan nongol. Biasanya mereka menggunakan susrug ato jala. Begitu keliatan ada bruelan di permukaan air, langsung aja di sergap pake susrug ato jala. Di sini mata kudu awas, kudu konsentrasi supaya kebagian ikan. (Praptanto, 2011)

Pak Jacobus Napiun mengatakan, Bahasa Betawi yang digunakan di Kampung Sawah adalah Bahasa Betawi pinggiran. Orang Kampung Sawah menyebutnya sebagai Bahasa Betawi "A". Bahasa Betawi pinggiran ini, atau dalam kajian mengenai masyarakat Betawi disebut sebagai Bahasa Betawi Ora, berbeda dengan Bahasa Betawi Kota. Bahasa Betawi Kota adalah bahasa yang digunakan oleh penduduk Betawi yang tinggal di Batavia atau daratan Jakarta. Bahasa Betawi Kampung Sawah mendapat pengaruh dari banyak bahasa lain, seperti Melayu, Sunda, Jawa, Arab, Cina, dan Belanda. (bandingkan dengan Praptanto, 2011) Dalam percakapan keseharian penduduk asli Kampung Sawah, terutama para orang tua, saat ini lebih didominasi oleh penggunaan Bahasa Indonesia dengan logat Betawi yang sangat kental. Akibat pekembangan penduduk yang tinggi, penggunaan Bahasa Betawi di Kampung Sawah mulai menurun.

Sangat sedikit anak-anak muda yang berbicara menggunakan Bahasa Indonesia dengan logat Betawi yang kentara, dan hampir tidak terdengar Bahasa Betawi dalam percakapan keseharian anak-anak muda tersebut.

Berbagai tradisi lain yang khas ditemui pada masyarakat Betawi di Jakarta juga dapat ditemui di Kampung Sawah. Upacara lebaran Betawi diselenggarakan setiap usai Idul Fitri di halaman Masjid AlJauhar, upacara sedekah bumi atau bebaritan juga kerap diselenggarakan setiap tahunnya oleh warga Katolik dan Kristen di gereja masing-masing. Pada setiap perayaan hari 
besar keagamaan ataupun nasional, banyak warga yang menggunakan pakaian khas Betawi seperti peci berwarna merah atau hitam, baju sadariah atau banyak mengenal sebagai baju koko, celana komprang berwarna hitam, sarung yang dikalungkan di leher, dan sabuk hijau yang dikenakan para pria. Sedangkan wanitanya mengenakan baju kurung atau kebaya, kain batik khas Betawi, serta kerudung sebagai penutup kepala. Penganan-penganan khas Betawi seperti dodol, wajik berwarna-warni, kembang goyang, dan lainnya juga dihidangkan dalam kegiatan-kegiatan ini.

Suku Betawi di Kampung Sawah juga memiliki ciri khas lain yang membedakan mereka dengan suku Betawi lainnya, yaitu penggunaan marga sebagai nama belakang mereka. Asal-usul penggunaan marga di belakang nama penduduk asli berkaitan erat dengan masuknya agama Kristen di Kampung Sawah. Hal ini juga memiliki keterkaitan dengan pemberlakuan hukum kolonial semasa penjajahan Belanda pada abad sembilan belas. Pada saat itu, diterapkan hukum yang berbeda, yaitu hukum Islam, hukum adat, dan hukum Barat. Bagi warga Kristen pribumi yang hendak menikah, berlaku peraturan bahwa mereka harus menggunakan nama keluarga dari pihak Ayah di belakang nama mereka ditambah dengan nama baptis, mirip dengan yang berlaku di negara-negara Eropa Barat. (Jamaludin, 2015) Menurut Pak Mihardja, setidaknya ada sepuluh nama marga tertua yang menjadi asal-usul marga lain di Kampung Sawah. Di antaranya adalah Rikin, Dani, Napiun, Baiin, dan lainnya. Saat ini, terdapat lebih dari dua puluh lima nama marga yang digunakan oleh penduduk Betawi Kampung Sawah. Setiap marga melarang perkawinan antar sesama anggota marga namun memperbolehkan perkawinan antar marga meski berlainan agama.

Sebagai akibat dari praktik perkawinan antar marga dan berlainan agama ini, di Kampung Sawah kita dapat menjumpai satu keluarga dengan keyakinan agama yang berbeda-beda di antara anggota keluarganya. Bapak dan Ibunya beragama Katholik, anakanaknya ada yang beragama Islam, beragama Kristen. Sebagai contoh adalah KH. Rahmadin
Afif, salah satu sesepuh dan pemuka agama Islam terkemuka di Kampung Sawah dan pemilik Yayasan Pendidikan Fisabilillah (Yasfi), yang memiliki adik perempuan yang beragama Kristen. Beliau juga terlahir dari kakek dan nenek yang beragama Kristen. Pak Jacobus Napiun, yang juga tokoh Katholik di Kampung Sawah, memiliki adik beragama Islam. Menurut Pak Jacobus Napiun, saat mempertanyakan keputusan adiknya untuk memeluk Islam, apapun agama yang dipeluk dan diyakini, jalani dengan sebenarnya. Jika agama itu yang dapat memberikan kedamaian dan kebahagiaan dalam hidup, maka jalani agama itu dengan sebenarnya. Namun demikian, saat ini sudah jarang dijumpai perkawinan silang antar agama, terutama antara penduduk Muslim Kampung Sawah dengan penduduk lain yang beragama nonIslam.

Penggunaan marga saat ini tidak terlalu berkaitan dengan keyakinan agama, namun warga asli Kampung Sawah yang menggunakan marga identik dengan keyakinan agama tertentu. Mereka yang masih menggunakan nama marga di belakang nama mereka saat ini biasanya beragama Kristen atau Katholik, meski tidak sedikit warga asli Kampung Sawah yang beragama Islam yang menggunakan marga di belakang nama mereka. Namun, kebanyakan warga muslim Kampung Sawah akan menyematkan nama ayah mereka dengan istilah "bin atau ibnu" bagi pria dan "binti" bagi wanita seperti kebanyakan kaum muslim lain. Meski demikian, sebagai dampak dari perkawinan antar marga dan antar agama di masa lalu, sistem kekerabatan masyarakat Kampung Sawah menjadi luas dan kuat. Antara satu penduduk Kampung Sawah yang satu dengan lainnya saat ini bisa dipastikan memiliki hubungan kekerabatan jika ditarik ke jalur kakek atau nenek buyut mereka.

Identitas kebetawian di Kampung Sawah ini berbeda dengan pandangan yang luas beredar bahwa kebetawian identik dengan keberislaman. Agama Islam menjadi pedoman utama dalam kehidupan orang Betawi, yang dapat dikatakan Islam merupakan urat nadi kebudayaan Betawi. Seolah-olah setiap orang Betawi adalah muslim, jika ada orang Betawi 
yang tidak berislam bukanlah orang Betawi. Kondisi ini merupakan bagian dari warisan sejarah di mana orang Betawi menganggap bahwa agama selain Islam merupakan keyakinan yang dianut pihak penjajah Belanda, sehingga siapa pun yang menganut keyakinan selain Islam adalah bagian dari penjajah Belanda. (Aziz, 2002; Asikin, 2013)

\section{Agama-agama Di Kampung Sawah}

Penduduk Kampung Sawah pada awalnya, seperti diyakini Pak Mihardja, banyak yang memiliki kepercayaan animisme. Mereka kerap melakukan ritual-ritual yang berisi pembacaan mantra atau doa-doa yang diiringi dengan sesaji pada waktu-waktu tertentu. Informasi ini bisa jadi benar jika melihat komposisi penduduk Kampung Sawah di awal terbentuknya adalah prajurit-prajurit Kesultanan Mataram yang berasal dari berbagai daerah di Nusantara. Pada saat yang bersamaan, tidak sedikit penduduk yang sudah memeluk Islam, terutama prajurit Kesultanan Mataram yang berasal dari pulau Jawa. Namun demikian, prajurit yang beragama Islam ini belum menjalankan ajaran Islam sesuai dengan syariat Islam. Mereka, seperti dikemukakan Pak Mihardja berdasarkan kisan-kisah dari orang-orang tua, mencampuradukkan ajaran Islam dengan ajaran-ajaran khurafat. Salah satu tradisi yang masih sempat disaksikan oleh Pak Mihardja adalah tradisi sesaji atau bebaritan, sebuah tradisi yang dalam masyarakat agraris disebut sebagai sedekah bumi. Tradisi ini dilaksanakan setiap hendak memulai masa tanam atau setelah musim panen, yang dalam ritualnya melakukan sesaji hasil bumi sembari membaca gabungan doadoa yang biasa dibaca oleh kaum muslim dengan mantra-mantra warisan leluhur.

Agama Kristen sudah ada di Kampung Sawah, menurut Pak Mihardja dan Pak Jacobus Napiun, sejak tahun 1870an. Pak Jacobus Napiun bahkan menyatakan, bahwa pada 1874 sudah berdiri cikal-bakal GKP Kampung Sawah. Pada masa ini, tercatat ada enam putra-putri setempat yang telah dibaptis. Perkembangan Kristen semakin meningkat pada 1880an, saat Kampung Sawah didatangi penduduk dari Jepara dan Jember. Penduduk asal Jepara ini merupakan murid-murid dan jemaat Kiai Ibrahim Tunggul Wulung, sedangkan penduduk yang berasal dari Jember merupakan murid-murid dan jemaat Kiai Sadrach. Kiai Ibrahim Tunggul Wulung dan Kiai Sadrach merupakan penginjil yang menyebarkan ajaran Kristen di wilayah Jawa Tengah dan Jawa Timur. Keduanya merupakan kolega penginjil asal Belanda, Frederick Lodewijk (FL) Anthing. FL. Anthing ini memiliki peran besar dalam penyebaran agama Kristen selama akhir abad ke-19 di pulau Jawa terutama di tatar Sunda. Beliau menyebarkan ajaran Kristen secara independen tanpa bantuan dari pemerintah Belanda.

Tahun 1886 jumlah penganut Kristen sudah berkembang dengan jumlah jemaat mencapai 100 orang lebih. Perkembangan jemaat kristiani di Kampung Sawah ini tidak lepas dari peran penting Paul Rikin, salah satu tokoh masyarakat yang disegani di Kampung Sawah pada saat itu. Beliau dan keluarga mendapat perkabaran Injil dari murid-murid FL. Anthing. Dari keluarga Paul Rikin ini kemudian muncul Lukas Rikin dan Laban Rikin, kedua anak Paul Rikin, yang menjadi tokoh agama dan tokoh pengembang pendidikan pertama di Kampung Sawah. Dari keluarga Rikin ini juga kemudian berkembang lembaga pendidikan modern pertama di Kampung Sawah, mungkin juga Bekasi, yang membuat penduduk Kampung Sawah mengenal kemampuan membaca dan menulis aksara latin.

Meski perkembangan jemaat Kristiani meningkat pada tahun ini, namun mereka terkotak-kotak dalam tiga kelompok. Ketiga kelompok jemaat ini bertempat di lokasi yang berbeda, yaitu kelompok jemaat Kampung Sawah Barat yang dipimpin oleh Bapak Lukas Rikin, kelompok jemaat Kampung Sawah Timur yang dipimpin oleh Bapak Mangun Ilang dan Bapak Yosef Baiin, dan kelompok jemaat Pondok Melati yang dipimpin oleh Bapak Nathanael dan Bapak Mathias. Terkotak-kotaknya jemaat Kristiani ini terjadi pasca mangkatnya FL. Anthing pada tahun 1883. Mangkatnya FL. Anthing membuat adanya kekosongan panutan pada posisi pengajar agama, terlebih FL. Anthing tidak memiliki ikatan apapun dengan pemerintah 
Belanda. Kekosongan yang menyebabkan pengelompokkan jemaat ini terdengar sampai ke negeri Belanda yang membuat pemerintah kolonial kemudian mengirim Nederlandsche Zendlings Vereeniging (NZV) atau Perhimpunan Perkabaran Injil Belanda. NZV ini merupakan perkumpulan para misionaris yang keberadaannya diakui secara resmi oleh dan mendapat dukungan dana dari pemerintah kolonial Belanda.

Pada 21 Maret 1886 datang seorang pendeta utusan NZV bernama C. Albers yang berusaha mengajak jemaat Kristen di Kampung Sawah yang berkelompokkelompok tersebut untuk bersatu dan bergabung di bawah naungan NZV. (Praptanto, 2011) Ajakan ini tidak bersambut baik dari seluruh jemaat yang terpecah-pecah tersebut. Karena ketiadaan pendeta yang dapat membimbing jemaat, dua kelompok bersedia bergabung ke dalam naungan NZV dengan pendeta C. Albers sebagai pimpinan jemaat. C. Albers sendiri tidak begitu rutin memberikan bimbingan kepada jemaatnya, sehingga pemahaman jemaat Kristen pada saat itu dapat dikatakan sangat minim. Meski bergabung dengan NZV, namun seluruh jemaat tetap menganggap bahwa mereka merupakan jemaat dari FL. Anthing. Jemaat ini yang hingga kini bernaung di bawah GKP Kampung Sawah. Penduduk asli Kampung Sawah sebagian besar merupakan bagian dari jemaat GKP Kampung Sawah.

Jika kedua kelompok jemaat Pak Lukas Rikin dan Pak Mangun Ilang bersedia bergabung dengan NZV, berbeda dengan jemaat di bawah pimpinan Bapak Nathanael dan Bapak Mathias. Pada tahun 1891 Pak Nathanael mendirikan gereja sendiri di Pondok Melati dengan jumlah jemaat tidak lebih dari 50 orang. Namun, perselisihan dalam tubuh kepengurusan gereja Kristen Kampung Sawah sejak 1886 belum hilang benar, sehingga Pak Nathanael dipecat.

Pada tahun 1896, Pak Nathanael bersama beberapa kawannya pergi ke Batavia karena mendengar tentang Kristen Katholik Roma dari tetangga-tetangganya yang bekerja di Batavia. Ia bermaksud untuk menjadi bagian dari jemaat Katholik Roma. Sampai di komplek pastoran Kathedral di Batavia, ia ditemui Bernardus Schweitz, S.J. Mendengar Keinginan Pak Nathanael, Pastor Schweitz mengatakan bahwa keinginan Pak Nathanael akan dipertimbangkan selama mereka mau mempelajari keyakinan dan mengikuti tata cara peribadatan Katholik Roma. Permintaan Pastor Schweitz ini disetujui oleh Pak Nathanael yang kemudian ditindaklanjuti oleh Pastor Schweitz dengan mengirim Bapak Suradi, yang tinggal di Kwitang-Kalipasir, untuk membuka pelajaran khusus bagi para warga Kampung Sawah yang ingin menjadi Katolik. Para katekumen pertama ini adalah Nathanael, Tarup Noron dan Markus Ibrahim Kaiin. Ketiganya, sebelumnya telah menjadi guru injil jemaat Protestan. Selain itu ada Yosef Baiin dan Sem Napiun. (Praptanto, 2011)

Tanggal 22 Juni 1896, Pak Nathanael pun dibaptis oleh Pastor Schweitz dan menjadi pimpinan jemaat Katholik pertama. Usai pengangkatan Pak Nathanael sebagai pimpinan jemaat, Pastor Schweitz mengunjungi Kampung Sawah. Puncaknya kunjungan Pastor Schweitz adalah pada tanggal 6 Oktober 1896, ketika ia membaptis 18 anak Kampung Sawah. Tanggal ini kemudian ditetapkan sebagai hari "kelahiran" umat Katolik Kampung Sawah. Jemaat Kaholik semakin hari semakin banyak, sehingga membutuhkan tempat peribadatan sendiri. Tahun 1897 berdiri sebuah "gereja" yang masih sangat sederhana. Gereja kecil ini mampu menampung sekitar 50 umat. Pak Nathanael pun diangkat menjadi ketua stasi dan guru agama. Bersama guru pembantu bernama Markus Ibrahim Kaiin dibuka juga semacam sekolah bagi anak-anak kampung. Saat ini, setelah beberapa kali renovasi, gereja kecil tersebut telah menjadi gereja megah yang mampu menampung ribuan jemaat bernama Gereja Katholik Santo Servatius.

Meskipun umat Kristen dan Katholik sudah memiliki rumah ibadah sendiri sejak abad ke-19, namun mayoritas penduduk Kampung Sawah merupakan penganut Islam. Pak Sholehudin Malik, putra KH. Rahmadin Afif mengatakan, bahwa dari kisah-kisah yang diceritakan Abah beliau, saat itu Islam hanya identitas saja bagi sebagian besar penduduk Kampung Sawah. Namun dalam praktik 
kesehariannya, mereka masih mencampuradukkan tradisi-tradisi agama leluhur. Seperti dikatakan Pak Sholehudin, jika mereka memasuki tempat-tempat yang dianggap keramat, maka mereka akan memberikan sesaji dan menggelar ritual khusus. Praktik-praktik agama leluhur ini, menurut Pak Mihardja, adalah praktik-praktik kepercayaan Buhun, kepercayaan yang banyak berkembang di wilayah Sunda dan Banten. Seperti dikatakan Pak Mihardja, salah satu tradisi Buhun yang masih dijumpai hingga tahun 1980an di Kampung Sawah adalah tradisi Bebaritan, sebuah tradisi semacam sedekah bumi. Tradisi ini adalah menggelar ritual dan sesaji di setiap bulan Suro. Warga akan berkeliling kampung dengan berjalan kaki dan pada saat tiba di setiap persimpangan jalan mereka akan menaruh sesaji berupa hasil bumi kemudian membaca mantra dan doa-doa. Pak Mihardja mengingat, doa-doa ini bercampur antara doa-doa yang biasa dibaca umat Islam dengan mantra-mantra yang diwariskan oleh leluhur.

Pak Sholehudin mengatakan, hingga tahun 1965 belum ada rumah ibadah bagi umat muslim di Kampung Sawah. Namun demikian, praktik keagamaan muslim tidak pernah diabaikan. Menurut Pak Mihardja, meski dalam kondisi yang demikian umat Islam masih melaksanakan ibadah sesuai dengan keyakinannya meski di rumah masing-masing. Dalam ingatannya, saat ia kecil, setiap usai maghrib ia mendengar lantunan ayat-ayat suci Al-Quran dari beberapa rumah warga. Setiap menunaikan shalat Jumat, warga Kampung Sawah akan berduyun-duyun menuju masjid di dusun sebelah. Pak Mihardja mengingat, hingga pertengahan dekade 1970an, warga Kampung Sawah menunaikan ibadah Jumat di sebuah masjid di Jatiluhur, Jatiasih yang jaraknya sekitar lima kilometer dari Kampung Sawah.

Rumah ibadah bagi kaum muslim, yakni sebuah mushala, baru dibangun pada tahun 1965 pasca meletusnya tragedi yang menewaskan 7 perwira Angkatan Darat (AD) di Jakarta. Mushala ini dibangun di atas tanah wakaf mlik keluarga Bagung dengan luas sekitar $200 \mathrm{~m}^{2}$. Pak Jacobus Napiun mengatakan, mushala ini dibangun sebagai salah satu bukti agar kaum muslim di Kampung Sawah benar-benar muslim dan bukan komunis yang tak beragama, yang saat itu diidentikkan dengan Partai Komunis Indonesia (PKI), partai yang dituduh menjadi dalang tragedi 65. Meski mushala sudah terbangun, namun gairah beribadah belum tumbuh di kalagan umat muslim. Pak Sholehudin mengatakan, hingga dekade 1970an, umat Islam di Kampung Sawah hanya sedikit yang mau memakmurkan mushala. Ini disebabkan, ketiadaan guru atau pemuka agama Islam yang mampu mengajarkan pemahaman Islam sesuai syariat. Mereka menjalankan agama hanya sesuai dengan apa yang diwariskan atau diajarkan dari orang tua mereka. Inilah salah satu penyebab terjadi perkawinan antar agama di Kampung Sawah.

Sepuluh tahun setelah mushala dibangun, gairah untuk menjalankan Islam secara baik sesuai syariat semakin tumbuh saat Pak Rahmadin Afif, putera asli Kampung Sawah, kembali usai menempuh pendidikan di Pesantren Al-Masthuriah, Sukabumi. Beliau awalnya mendirikan Madrasah Diniyah Awwaliyah yang diperuntukkan bagi umat muslim di Kampung Sawah. Madrasah diniyah ini pada tahun 1977 dikembangkan menjadi sebuah pesantren yang berada di bawah naungan Yayasan Fisabilillah (Yasfi). Nama Fisabilillah ini merupakan bentuk penghargaan Yasfi kepada Yayasan Haji Fisabilillah yang banyak memberikan bantuan dana bagi berdirinya pesantren ini. Bersamaan dengan berdirinya pesantren Yasfi ini, berdiri pula masjid pertama di Kampung Sawah. Masjid ini berdiri di sisi Timur Jl. Raya Kampung Sawah, yang pada tahun pada tahun 1982 kemudian dipindah ke sisi Barat Jl. Kampung Sawah dan diberi nama Masjid AlJauhar. Masjid ini kini berdiri berdampingan dengan asrama putera Pesantren Yasfi dan Gelanggang Olah Raga (GOR) Yasfi.

\section{Hubungan Antar Umat Beragama}

Gambaran mengenai hubungan antar umat beragama di Kampung Sawah dapat dilihat pada setiap pelaksanaan shalat Jumat di Masjid Al-Jauhar. Saat shalawat kepada Nabi Muhammad SAW dilantunkan untuk menyambut masuk waktu shalat Jumat, tepat 
di saat waktu menunjukkan pukul 12 siang, akan terdengar dentang lonceng dari Gereja St. Servatius yang terletak sekitar 20 meter di sebelah Timur Laut dari Masjid Al-Jauhar. Bahkan, sering terjadi dentang lonceng gereja terdengar pada saat khotib menyampaikan khutbah. Jika diperhatikan dengan seksama, suara pengeras masjid saat shalawat dilantunkan disetel untuk hanya dapat didengar oleh jamaah di dalam masjid dan terdengar keluar tidak lebih dari jarak radius 10 meter. Pengeras suara akan terdengar oleh jamaah di luar masjid hanya pada saat azan dikumandangkan. Saat khotib menyampaikan khutbahnya, pengeras suara akan kembali hanya terdengar oleh jemaah di dalam masjid. Masjid Al-Jauhar yang berada di dalam kompleks Pesantren Yasfi seolah menjadi mercusuar toleransi kehidupan beragama bagi kelompok masyarakat muslim di Kampung Sawah. Dari masjid ini, KH. Rahmadin Afif mengajarkan kepada kaum muslim di Kampung Sawah untuk menghargai keberagamaan warga lain yang tinggal di Kampung Sawah. Beberapa warga Kampung Sawah, yang ditemui untuk keperluan penelitian ini, mengatakan bahwa Pak Kiai Rahmadin menjadi salah satu tokoh agama dan masyarakat yang menjadi panutan, tidak saja bagi kaum muslim, namun juga umat agama lain yang tinggal di Kampung Sawah. Dalam suatu pengajian di Masjid Al-Jauhar pernah terjadi salah satu penceramah menyinggung hubungan antara agama dalam ceramahnya. Isi ceramahnya dirasa tidak sesuai dengan situas Kampung Sawah. Pak Kiai Rahmadin kemudian memerintahkan salah seorang santrinya untuk mematikan pengeras suara yang mengarah keluar masjid, sehingga isi ceramah hanya dapat didengar oleh jamaah di dalam masjid. Dalam beberapa kesempatan lain, jika mendapati penceramah dengan materi ceramah yang menyinggung kehidupan umat beragama di Kampung Sawah, Pak Kiai Rahmadin akan memberikan ceramah yang isinya menjelaskan kondisi Kampung Sawah, sehingga tidak menyinggung perasaan si penceramah dan dapat menenangkan jamaah. Pak Sholehudin Malik mengatakan, dalam beberapa kesempatan banyak jamaah masjid yang menghendaki Pak Kiai Rahmadin mengundang salah satu pemuka agama di Jakarta yang sangat kondang namun terkenal dengan isi ceramah yang sangat keras, kontroversial, dan provokatif. Pak Kiai Rahmadin menjelaskan kepada jamaahnya, bahwa pemuka agama yang dimaksud tidak sesuai untuk dihadirkan dengan kondisi dan situasi Kampung Sawah.

Kondisi damai di Kampung Sawah saat ini tercipta bukan dari aktivisme yang singkat, melainkan sudah dibentuk sejak lama. Pak Jacobus Napiun, misalnya, berscerita bahwa saat ia kecil hal paling menyenangkan adalah menunggu malam Idul Fitri tiba jika Ramadhan akan berakhir. Ia dan kawankawannya yang muslim akan bergantian menabuh beduk mengiringi kumandang takbir di malam hari raya tersebut. Pak Mihardja memiliki cerita yang lain, bahwa saat kecil ia sangat senang jika puasa Ramadhan berakhir atau Lebaran tiba. Sebab, saat-saat itulah ia akan kebanjiran undangan untuk menghadiri acara selamatan yang dibuat oleh saudarasaudaranya atau tetangganya yang muslim sebagai bentuk rasa syukur usai menjalankan puasa Ramadhan sebulan penuh. Keluargakeluarga Kristiani pun akan mengirimkan hantaran kepada keluarga-keluarga muslim. Demikian halnya jika Natal tiba, keluargakeluarga Kristiani akan mengirimkan hantaran kepada keluarga muslim sebagai bentuk berbagi rasa syukur dan kebahagiaan. Sedangkan keluarga-keluarga muslim akan datang berkunjung membawa hantaran dan memberikan ucapan selamat.

Saling kunjung pada hari raya keagamaan saat ini masih terjadi meski mulai berkurang dilakukan oleh warga. Salah satu warga yang masih mempraktekkan ini adalah Pak Kiai Rahmadin. Pak Budiman, salah satu tokoh masyarakat dan mantan Kepala Sekolah di SDN 01 Jati Murni bercerita, saat Natal tahun lalu (tahun 2017), Pak Kiai Rahmadin bekeliling menyambangi rumah-rumah keluarga Kristiani, terutama rumah-rumah para sesepuh. Beberapa tokoh masyarakat muslim lain juga melakukan hal yang sama. Pak Sudirman, salah satu tokoh masyarakat dan jamaah majelis taklim mingguan di Masjid Al-Jauhar yang berhasil diwawancara, menyatakan bahwa ia tidak merasa bermasalah 
untuk mengucapkan Selamat Natal kepada warga dan tetangga kristiani. Ia menyatakan bahwa semua tergantung kepada niat kita mengucapkan Selamat Natal. Yang ia lakukan, menurutnya, tidak diniatkan untuk mengamini keyakinan umat agama lain, melainkan menjaga persaudaraan dengan warga lain.

Pak Mihardja menuturkan, bahwa meski ia diperbolehkan makan babi, namun orang tuanya tidak memperbolehkan ia dan anggota keluarganya yang lain untuk makan babi menggunakan piring dan sendok. Kedua orang tuanya akan meminta ia dan anggota keluarga yang lain untuk memetik dedaunan dari kebun, baik daun pisang atau daun lain yang dapat dijadikan sebagai alas makan. Jika ada yang menggunakan piring dan sendok untuk memakan babi di keluarga Pak Mihardja, maka orang tuanya akan memarahinya. Sebab, piring dan sendok kadang kala digunakan untuk menjamu tetangga-tetangga atau saudara-saudara muslim yang berkunjung, karenanya tidak baik menyajikan penganan menggunakan alas yang sudah digunakan untuk memakan makanan yang menurut keyakinan muslim dihukum haram. Pak Mihardja secara sederhana menjelaskan, makanan yang kamu sukai mungkin saja tidak disukai oleh orang lain. Karena itu, makanlah tapi jangan sampai orang lain tahu apa yang kamu makan.

Pak Mihardja memandang soal keyakinan yang berbeda di antara warga Kampung Sawah layaknya pakaian. Dalam satu keluarga, meski berasal dari Bapak dan Ibu yang sama, namun selera berpakaian akan berbeda-beda. Karenanya, apa pun yang dikenakan selama dirasa pas dan nyaman saat dipakai, maka silakan dipilih dan dipakai. Namun yang mesti dikedepankan adalah etika kekeluargaan. Siapa pun, tidak memandang agama yang diyakini, jika sudah tinggal di Kampung Sawa harus diperlakukan sebagai saudara, terlebih dengan saudara sendiri.

Interaksi antar warga juga terjadi dalam keseharian di berbagai ruang publik. Sebagai contoh, Gereja St Srvatius memiliki klinik pengobatan di bagian belakang. Pengunjung klinik ini tidak saja jemaat gereja melainkan juga penduduk sekitar gereja, apa pun agamanya. Ibu Murni, pengelola klinik, mengatakan bahwa klinik ini terbuka untuk umum sebagai bentuk pelayanan gereja untuk warga sekitar. Setiap pengunjung dikenai tarif yang sama, tidak melihat apakah ia jemaat gereja atau bukan. Suatu saat peneliti melihat satu keluarga mengendarai sepeda motor, terdiri dari suami, istri menggunakan jilbab, dan seorang anak memasuki gereja. Mereka bertanya kepada satpam gereja apakah klinik buka atau tidak. Hanya saja hari itu, Sabtu, merupakan hari di mana klinik tutup tidak melayani pasien. Menurut Ibu Murni, di hari Minggu pun ada juga pengunjung muslim yang berobat di klinik tersebu, meski bersamaan dengan jadwal kebaktian di gereja.

Pak Budiman mengatakan bahwa pada saat ia masih menjadi Kepala SDN 01 Jati Murni ia pernah menginisiasi kegiatan semacam pertukaran pelajar lintas agama dalam kegiatan-kegiatan peringatan hari besar keagamaan. Pada saat peringatan Maulid Nabi Muhammad SAW, maka akan diutus dua hingga tiga orang siswa Kristiani untuk menghadiri kegiatan tersebut. Demikian sebaliknya, saat ada peringatan Natal diutus beberapa siswa Muslim untuk menghadiri acara tersebut. Hal ini, menurut Pak Budiman, untuk memperkenalkan anak-anak yang bersekolah di SDN 01 Jati Murni dengan keragaman agama yang ada di Kampung Sawah.

Berbagai aktivitas yang mempertemukan warga Kampung Sawah juga kerap dilakukan. Salah satu contohnya adalah pendirian Komunitas Suara Kampung Sawah (KSKS) yang menelurkan ide membuat Radio Kampung Sawah dan buletin bulanan. Radio dan buletin ini menyajikan berbagai informasi mengenai Kampung Sawah, mulai dari sejarah dan kebudayaan Kampung Sawah, kegiatankegiatan yang akan berlangsung, dan lainnya. Sayangnya, radio dan buletin ini vakum sejak pertengahan tahun 2017.

Koperasi simpan pinjam juga banyak berdiri di Kampung Sawah. Koperasi ini menjadi salah satu wadah bagi warga Kampung Sawah untuk berinteraksi tanpa batasan keyakinan apa pun. Pak Jacobus Napiun, bersama empat orang lain, merupakan salah satu tokoh masyarakat yang berinisiatif mendirikan koperasi jenis ini di Kampung 
Sawah. Anggotanya bahkan sebagian besar adalah penduduk muslim. Namun, rasa percaya terhadap pengurus dalam mengelola koperasi menjadi dasar keinginan mereka untuk bergabung dalam koperasi yang dikelola oleh Pak Jacobus.

Aktivitas-aktivitas lain dalam menjaga kedamaian dan memperkuat kerukunan warga Kampung Sawah juga kerap diselenggarakan. Gereja St. Servatius setiap tanggal 13 Mei selalu mengadakan acara sedekah bumi. Kegiatan ini biasanya diisi dengan berbagai kegiatan budaya yang mengikutsertakan berbagai elemen warga di Kampung Sawah. Pesantren Yasfi tahun lalu menggelar acara Lebaran Betawi yang juga melibatkan banyak warga Kampung Sawah. Pesantren ini juga tak jarang menggelar berbagai kegiatan terutama dialog antara umat beragama yang melibatkan berbagai pembicara tingkat nasional. Pak Sholehudin Malik, melalui Forum Nasional (Fornas) Bineka Tunggal Ika pada 22 Juli 2017 juga menyelenggarakan kegiatan Perjalanan Mengenal Kebhinekaan. Kegiatan yang dilaksanakan selama satu hari ini diperuntukkan bagi anak-anak dari berbagai suku dan agama dengan tujuan mengenalkan keragaman yang ada di sekitar Kampung Sawah kepada anak-anak.

\section{Ujian dan Tantangan Kehidupan Beragama}

Kerukunan yang terwujud di Kampung Sawah tidak terlepas dari berbagai ujian yang terus muncul hingga hari ini. Ujian ini yang membuat Kampung Sawah terus belajar memperkuat kerukunan untuk menjaga kedamaian yang selama ini telah tercipta. Pendirian Gereja Stanislaus Koska dan Balai Banjar Hitakarma adalah beberapa di antaranya. Meski Gereja Stanislaus Koska dibangun di luar wilaya Kampung Sawah, yaitu di Kranggan, namun konflik yang muncul atas pendirian gereja ini juga sedikit berimbas kepada Kampung Sawah. Sebab, Gereja Stanislaus Koska ini dibangun akibat Gereja St. Servatius sudah tidak mampu menampung jemaat yang jumlahnya sudah mencapai belasan ribu. Tidak sedikit penduduk Kampung Sawah yang ikut berdemonstrasi menentang pendirian gereja yang diklaim oleh para pedemo sebagai yang terbesar di Asia Tenggara.

Karena hubungan kekerabatan dengan penduduk Kranggan, bakal bangunan Gereja Stanislaus Koska dijaga oleh sebagian warga Kampung Sawah, terutama mereka yang beragama Katholik. Pak Saptadi, salah seorang yang ikut berjaga saat itu bercerita, pernah ia bertanya kepada salah seorang Saudaranya yang hendak ikut berdemo menentang pendirian gereja tersebut; mau apa ikut-ikut demo menentang pendirian gereja? Saudaranya menjawab, bahwa ia ingin ikut serta menentang pendirian gereja terbesar seAsia Tenggara. Pak Saptadi kemudian menjelaskan, bahwa gereja yang akan dibangun merupakan gereja Katholik dan masih bagian dari gereja St. Servatius, artinya masih saudara sendiri. Mendengar penjelasan Pak Saptadi ini, saudaranya tersebut akhirnya urung ikut dalam demonstrasi menentang pendirian gereja di Kranggan tersebut.

Pendirian Balai Banjar Hitakarma juga menjadi salah satu ujian kerukunan di Kampung Sawah. Balai Banjar Hitakarma sebenarnya dibangun sebagai sarana pendidikan bagi anak-anak umat Hindu yang tidak mendapat mata pelajaran agama yang cukup di sekolah. Anak-anak dari berbagai agama yang hidup di Kampung Sawah biasanya menyekolahkan anak-anak mereka di Sekolah Strada, sebuah sekolah dengan tradisi Katholik yang dibangun sejak tahun 1930an. Balai Banjar Hitakarma menyelenggarakan pendidikan agama setiap hari Minggu. Ujian pendidikan agama bagi anak-anak beragama Hindu ini yang nantinya dikirim ke sekolah mereka masing-masing untuk memenuhi nilai mata pelajaran agama. Sayangnya akibat ketidaktahuan, banyak warga muslim yang kemudian menentang pendirian balai pendidikan ini.

Pendirian Balai Banjar Hitakarma ini ditentang oleh pengurus sebuah masjid karena dianggap sebagai rumah ibadah. Kebetulan juga, pengurus masjid ini adalah warga pendatang dan bukan penduduk asli Kampung Sawah. Ia menganggap pendirian balai pendidikan ini tidak sesuai dengan syaratsyarat yang diatur dalam Peraturan Bersama Menteri (PBM) Agama dan Menteri Dalam 
Negeri Nomor 6 tahun 2004. Pak Saptadi, bersama beberapa warga asli Kampung Sawah lain saat itu dan panitia pembangunan Balai Banjar Hitakarma, menjelaskan kepada pengurus masjid bahwa pendirian balai ini sudah mendapat izin dari RT dan RW. Selain itu, di Kampung Sawah ini siapa pun berhak mendirikan rumah ibadah. Sebab beribadah merupakan hak setiap warga sesuai keyakinan yang dianut.

Selain berbagai ujian terhadap kerukunan di atas, kondisi damai di Kampung Sawah menghadapi tantangan yang mesti dihadapi dan dipikirkan oleh seluruh elemen warga. Pesatnya pembangunan di Kampung Sawah, terutama pembangunan jalan yang mempermudah akses dari dan menuju Kampung Sawah, membuat Kampung Sawah menjadi semacam magnet bagi penduduk dari luar yang hendak memiliki tempat tinggal. Terlebih, Kampung Sawah terkenal dengan berbagai fasilitas sarana rumah ibadah namun tetap mampu menjaga kondisi damai antar warganya. Hal ini membuat Kampung Sawah kini banyak dipenuhi kompleks perumahan yang tersegregasi dari pemukimanpemukiman atau perkampungan penduduk asli atau yang sudah lama menetap.

Perumahan-perumahan ini, seperti dikatakan Pak Jacobus Napiun, kerap berlaku eksklusif. Sudah pun penghuninya jarang beraktivitas bersama dengan warga asli akibat aktivitas harian yang sudah padat, pemukimanpemukiman ini juga membangun temboktembok pemisah yang makin membatasi pergaulan mereka dengan penduduk setempat. Hal ini pernah diprotes oleh Pak Jacobus kepada pengembang perumahan-perumahan tersebut, namun tidak memiliki dampak yang signifikan. Dengan ekslusivitas pemukimanpemukiman ini, pengenalan terhadap nilainilai lokal tentu saja tidak akan tercapai.

Kampung Sawah sebenarnya tidak asing dengan penduduk pendatang, sebab sudah sejak lama wilayah ini kedatangan banyak penduduk baru. Jika hingga tahun 1990an penduduk pendatang yang mau bermukim di Kampung Sawah mau berbaur dengan penduduk asli di perkampungan, berbeda dengan kondisi sepuluh tahun belakangan. Pak Jacobus Napiun mengatakan, dahulu para pendatang yang berasal dari Flores kerap mengadakan pesta di rumah-rumah jika mereka merayakan sesuatu.

Hal ini tentu saja mengganggu penduduk yang tidak terbiasa dengan hal ini. Pak Jacobus kemudian memanggil salah seorang penduduk yang dituakan di antara pendatang asal Flores tersebut. Ia kemudian diberitahu mengenai budaya dan tradisi di Kampung Sawah yang tidak mengenal pestapesta seperti itu. Beliau mengatakan kepada sesepuh pendatang asal Flores tersebut, bahwa meski sama-sama menganut Katolik, ia tidak mengenal pesta-pesta seperti yang dilakukan mereka. Jangan sampai kemudian citra Katolik tercoreng dengan perilaku yang membuat penduduk setempat tidak nyaman. Pak Jacobus mengatakan, jika sudah minum air Kampung Sawah harus menjadi orang Kampung Sawah. Artinya, siapa pun yang sudah menetap di Kampung Sawah, ia harus mengikuti tradisi dan budaya Kampung Sawah. Hal ini yang tidak mampu ditransfer ke pendudukpenduduk yang tinggal di perumahanperumahan yang terpisah dari penduduk.

Pak Mihardja juga mengatakan bahwa banyaknya pendatang sedikit-banyak berdampak pada makin hilangnya nilai-nilai khas Kampung Sawah. Menurutnya, ia masih merasakan tradisi-tradisi yang mengandung nilai-nilai kearifan yang khas dilakukan oleh warga Kampung Sawah hingga tahun 1990an. Seiring masuknya pendatang pada tahun 1980an, tradisi-tradisi semacam sedekah bumi, selamatan saat akhir Ramadhan atau sore hari pertama Idul Fitri, ia ingat mulai hilang perlahan mulai tahun 1980an dan benar-benar tidak muncul lagi pada tahun 1990an. Ia mencontohkan, jika dahulu ia bahkan tidak boleh makan babi menggunakan piring dan sendok, kini penduduk pendatang seenaknya membakar babi di pekarangan.

Pengaruh media sosial juga menjadi tantangan terbaru dalam kehidupan beragama warga Kampung Sawah saat ini. Hal ini dikemukakan tidak saja oleh para pemuka agama Kristen, seperti Romo Agustinus Purwantoro dan Pak Budiman Dani, namun juga oleh Pak Sholehudin Malik. Romo Agustinus mengatakan, kehidupan antar umat beragama di Kampung Sawah mendapat 
tantangan dari makin heterogennya Kampung Sawah. Dua puluh atau tiga puluh tahun lalu toleransi di Kampung Sawah masih mampu diandalkan, karena komposisi penduduk yang masih homogen.

Namun kondisi kini sudah jauh berbeda. Penduduk pendatang yang makin masif datang dengan berbagai keyakinan yang mereka miliki. Menurut Romo Agustinus, radius dua hingga tiga kilometer persegi dari titik pusat Kampung Sawah, ia masih optimis toleransi dan kerukunan masih terjaga. Namun lebih dari itu, di mana penduduk pendatang menempati berbagai pemukiman baru, kondisi yang berbeda akan mudah ditemui.

Pengaruh media sosial juga menjadi tantangan tersendiri dalam merawat dan menjaga kondisi damai di Kampung Sawah. Kampung Sawah kini, menurut Romo Agustinus, juga perlu dilihat interaksinya dengan dunia luar yang lebih luas, dan media sosial mampu menembus dinding penjaga Kampung Sawah. Setidaknya dalam kurun waktu dua tahun belakangan, ia banyak menerima laporan dari jemaatnya mengenai kondisi yang berbeda dari tahun-tahun sebelumnya. Ujaran-ujaran yang tidak mengenakkan, ajakan-ajakan untuk tidak bergaul dengan yang tidak seiman kerap didengar oleh jemaatnya.

Hal yang sama dirasakan oleh Pak Budiman Dani, salah seorang tokoh masyarakat beragama Kristen. Ajakan-ajakan untuk tidak bergaul dengan non-muslim yang kadang ia dengar atau baca melalui media sosial, ia rasakan berdampak dalam kehidupan bermasyarakat. Dalam dua tahun belakangan ia merasa ada yang berubah saat Idul Fitri dan Natal. Jika dahulu banyak warga saling kunjung, kini hal itu sudah mulai berkurang. Bahkan, salah seorang warga yang pernah menjadi muridnya di SD dahulu, kina hampir tidak mau menyapa jika berpapasan di jalan. Romo Agustinus dan Pak Sholehudin Malik sependapat, bahwa heterogenitas yang kini terjadi di Kampung Sawah akibat banyaknya pendatang baru serta pengaruh media sosial menjadi tantang berat merekatkan kembali warga Kampung Sawah seperti tiga puhu tahun yang lalu.
Tantang lain yang mesti dihadapi oleh seluruh warga Kampung Sawah adalah proses regenerasi tokoh-tokoh yang mampu berperan menjadi perekat seperti yang saat ini dilakukan oleh para orang tua seperti Pak Kiai Rahmadin, Pak Jacobus Napiun, Pak Budiman Dani, Pak Rihardja Rikin, dan lainnya. Peran tokohtokoh tersebut saat ini sangat kuat dan terasa pengaruhnya dalam menjaga kondisi damai di Kampung Sawah. Namun, sangat sedikit generasi muda yang mau meneruskan aktivisme yang sudah dimulai oleh para sesepuh Kampung Sawah tersebut.

Dari komunitas muslim, warga Kampung Sawah mampu berharap kepada Pak Sholehudin Malik, putra Pak Kiai Rahmadin yang juga Ketua Fornas Bineka Tunggal Ika Kota Bekasi. Namun, hingga penelitian ini usai dilaksanakan, belum terdengar anak-anak muda dari kelompok agama lainnya yang mau meneruskan perjuangan yang sudah dirintis para orang tua mereka

\section{Faktor-faktor Penopang Kerukunan Di Kampung Sawah}

Ada tiga komponen penting, berdasarkan hasil temuan lapangan di atas, yang saling berkelindan dan mampu menciptakan kerukunan antar umat beragama di Kampung Sawah. Komponen pertama adalah ikatan kekerabatan yang begitu erat di antara penduduk Kampung Sawah. Ikatan kekerabatan di antara warga Kampung Sawah yang sangat erat ini dapat ditelusuri sejak awal terbentuknya wilayah Kampung Sawah. Kawin-mawin yang terjadi di antara warga yang pada saat awal wilayah ini terbentuk masih sangat sedikit membuat Kampung Sawah menjadi sebuah kampung keluarga. Komunitas yang semula jumlah anggotanya sedikit ini menjadi semakin banyak akibat dari proses kawin-mawin tersebut. Meski jumlah anggotanya semakin bertambah, nilai-nilai keluarga masih menjadi pegangan dan dikedepankan dalam aktivitas sehari-hari.

Masuknya agama Kristen pada akhir abad ke-19, yang kemudian memunculkan sistem marga di Kampung Sawah, semakin memperluas kekerabatan di Kampung Sawah. Sistem ini melarang setiap anggota marga 
kawin dengan anggota marga yang sama. Setiap anggota marga hanya diperbolehkan kawin dengan anggota marga yang berbeda meskipun juga berbeda agama dan keyakinan. Meski saat ini sudah jarang dijumpai pernikahan berbeda agama, terutama antara penduduk beragama Islam dengan penduduk beragama lain, namun warisan dari aturan marga ini masih dapat dijumpai di Kampung Sawah, di mana satu keluarga memiliki anggota keluarga yang berbeda keyakinan.

Pernikahan antar marga dan antar keyakinan ini yang kemudian membuat Kampung Sawah menjadi semacam kampung keluarga. Fungsi keluarga dalam lingkup kecil, yaitu melindungi, memberikan efeksi, memberikan pengasuhan dan pendidikan, (Mainarno, 2011) kemudian diterapkan ke dalam keluarga dalam lingkup yang luas. Fungsi keluarga yang diterapkan dalam lingkup luas ini kemudian mampu menguatkan setiap anggota warga di Kampung Sawah. Kuatnya fungsi keluarga di Kampung Sawah membuat mereka terus memperkenalkan silsilah keluarga kepada keturunannya. Pengenalan silsilah keluarga ini juga disertai dengan berbagai keyakinan dan agama yang dianut setiap anggota keluarga. Proses ini yang memberikan pembelajaran kepada setiap warga Kampung Sawah mengenai keragaman keyakinan yang sudah ada sejak jaman leluhur mereka. Seperti dikemukakan Pak Mihardja, apapun agama yang diyakini setiap anggota keluarga, namun etika kekeluargaan harus dijunjung tinggi. Hal ini yang kemungkinan membuat Kampung Sawah melewati ujian pertama mereka pada akhir abad ke-19, yaitu pada saat terjadi perselisihan di kalangan anggota jemaat gereja yang membuat warga Kristiani terbagi menjadi Kristen Protestan dan Kristen Katholik.

Faktor kedua yang membuat Kampung Sawah mampu menjaga kondisi damai adalah peran tokoh masyarakat. Ikatan kekerabatan yang lekat di atas, mampu menjaga kondisi damai Kampung Sawah saat sebagian besar anggotanya merupakan kerabat akibat dari proses kawin-mawin yang terjadi sejak lama. Hal ini tidak akan cukup berfungsi saat Kampung Sawah mulai dihuni oleh banyak penduduk yang tidak saja terdiri dari warga asli Kampung Sawah, namun juga penduduk dari berbagai daerah di Indonesia. Mereka ini datang dengan membawa berbagai adat, tradisi, dan keyakinan yang berbedabeda. Peran tokoh masyarakat memiliki nilai pentingnya di sini. Merekalah yang mentransfer berbagai nilai dan tradisi lokal Kampung Sawah kepada setiap penduduk pendatang.

Pak Kiai Rahmadin, misalnya, kerap memperkenalkan keragaman di Kampung Sawah kepada setiap pendakwah yang diundang untuk mengisi berbagai kegiatan keagamaan di Masjid Al-Jauhar. Meski terkenal sebagai pemuka agama yang toleran, namun beliau juga dapat bersikap tegas kepada berbagai hal yang dianggap mampu mengancam kondisi kehidupan keagamaan di Kampung Sawah. Sebagai contoh, beliau menolak usulan banyak jamaah untuk mengundang pendakwah kondang namun terkenal dengan isi ceramah yang kontroversial dan provokatif. Sebagai Ketua Majelis Umat Beragama Kecamatan Pondok Melati, beliau juga tegas menolak permohonan izin mendirikan rumah ibadah jika jemaah pengguna rumah ibadah tersebut bukan penduduk yang benar-benar tinggal di Kecamatan Pondok Melati.

Selain Pak Kiai Rahmadin, ada juga Pak Jacob Napiun, Pak Mihardja Rikin, serta tokoh-tokoh masyarakat lainnya, termasuk juga para pemuka agama, yang menjaga kearifan lokal Kampung Sawah. Pak Jacobus Napiun misalnya, pernah menegur pendatang dari Flores yang kerap mengadakan pesta pada saat momen-momen tertentu yang dianggap sebagai bentuk rasa syukur. Pak Jacobus Napiun memanggil tokoh-tokoh masyarakat Flores di Kampung Sawah untuk mengingatkan mereka bahwa mereka tinggal di wilayah yang tidak mengenal tradisi pesta dalam mengekspresikan rasa syukur. Sehingga pesta-pesta yang mereka buat, bukan tidak mungkin mengganggu penduduk lain.

Sebagai sesama Katholik, seperti dikemukakan Pak Jacobus Napiun, jangan sampai pesta-pesta tersebut mencoreng keyakinan Katholik karena dianggap sebagai bagian dari ajaran Katholik. Yang sangat ditekankan oleh Pak Jacobus Napiun kepada 
mereka adalah, bahwa jika sudah meminum air di tanah Kampung Sawah, maka mereka sudah menjadi warga Kampung Sawah. Sehingga wajib menjaga dan menghormati adat tradisi Kampung Sawah.

Kuatnya peran tokoh masyarakat Kampung Sawah ini juga menjadi tantangan bagi warga Kampung Sawah untuk bisa lepas dari ketergantungan terhadap mereka. Hingga kini masih sedikit anak-anak muda Kampung Sawah yang mampu menjadi agen mediasi hubungan antar umat beragama ataupun antar sesama warga Kampung Sawah. Di antara yang sedikit itu adalah Pak Ust. Sholehudin Malik, putera Kiai Rahmadin Afif. Pak Ust. Sholehudin Malik sendiri merupakan ketua Forum Nasional Bhinneka Tunggal Ika Kota Bekasi yang telah beberapa kali menginisiasi berbagai kegiatan lintas agama di Kampung Sawah. Selain beliau, belum terlihat anak-anak muda dari luar komunitas Islam yang aktif menjadi penggerak kegiatan lintas agama di Kampung Sawah.

Kuatnya peran tokoh masyarakat dalam menjaga kondisi damai Kampung Sawah dengan mengedepankan berbagai kearifan lokal yang ada juga ditunjang dengan faktor penopang ketiga, yaitu modal sosial, yang ada di Kampung Sawah. Semakin tingginya heterogenitas penduduk Kampung Sawah membuat mereka harus mampu beradaptasi dengan perubahan yang ada. Berbagai aktivitas yang melibatkan berbagai elemen warga Kampung Sawah kerap dilaksanakan baik yang bersifat spontan ataupun terencana. Kegiatan-kegiatan yang sifatnya keseharian atau quotidian, dalam penjelasan Varshney, seperti saling kunjung saat hari raya keagamaan, gotong royong mengatur area parkir saat ada kegiatan keagamaan di rumah ibadah, dan berbagai kegiatan lain masih mudah ditemui di Kampung Sawah.

Di Kampung Sawah kadang kala juga diselenggarakan kegiatan dialog lintas agama yang menghadirkan pembicara dari berbagai kalangan di luar Kampung Sawah. Tujuan menghadirkan mereka ini, seperti dikemukakan oleh Pak Jacob Napiun, salah satunya adalah agar warga Kampung Sawah juga mempelajari berbagai kondisi kehidupan beragama di luar wilayah mereka. Hal ini dalam usaha memperkenalkan warga Kampung Sawah dengan perubahan yang terjadi di luar wilayah mereka, berbagai informasi mengenai kondisi sosial di luar Kampung Sawah. Dengan begini, mereka diharapkan juga mampu menyaring berbagai informasi yang mampu membangun Kampung Sawah menjadi lebih baik.

Kegiatan-kegiatan yang diinisiasi dengan melibatkan seluruh elemen warga Kampung Sawah atau bersifat asosiasional, dalam terminologi Varshney, seperti koperasi, arisan, dan perkumpulan lain juga tidak sedikit dapat ditemui di Kampung Sawah. Kegiatankegiatan ini, meski diadakan dalam skala lokal, yaitu dalam tingkatan RT atau RW, namun dapat mengikat penduduk dalam satu tujuan meningkatkan kesejahteraan anggota dan menciptakan Kampung Sawah secara luas menjadi wilayah yang nyaman dan damai.

Faktor-faktor seperti dijelaskan di atas menjadi penopang kondisi damai dan rukun di Kampung Sawah. Peran tokoh agama di masing-masing komunitas agama di Kampung Sawah dalam membina umatnya setidaknya menjadi penahan munculnya konflik antar umat agama akibat faktor endogen. Mereka mampu membuat ajaran agama dipahami tidak secara sempit dan formalistis. (Hayat, 2012) Mereka juga mampu menjadi penyeimbang informasi atas berbagai perkembangan kehidupan di luar wilayah Kampung Sawah (faktor eksogen) dengan menginisiasi berbagai kegiatan dialog lintas agama yang menghadirkan berbagai pembicara dari luar wilayah.

\section{PENUTUP}

Kondisi damai dalam hubungan antar umat beragama di Kampung Sawah yang terjaga hingga kini merupakan hasil dari aktivisme yang sudah berlangsung sejak lama, bahkan sejak awal Kampung Sawah dibangun. Peran faktor ikatan kekerabatan, tokoh masyarakat dan agama, dan modal sosial yang ada di Kampung Sawah berkelindan membuat Kampung Sawah mampu menjaga kondisi damai hingga saat ini. Ikatan kekerabatan menciptakan berbagai nilai-nilai kearifan lokal yang menyatukan warga Kampung Sawah 
sebagai satu keluarga. Tokoh masyarakat dan agama berperan besar dalam menjaga kearifan lokal tersebut dan mentransformasikannya kepada penduduk pendatang. Modal sosial yang tercipta kemudian menyatukan Kampung Sawah yang kini heterogen menjadi wilayah yang dapat menerima berbagai adat, tradisi, dan keyakinan yang berbeda.

Tantangan yang dihadapi warga Kampung Sawah dalam menjaga kondisi damai dalam hubungan antar umat beragama saat ini setidaknya mencakup dua hal; terjangan arus informasi melalui media sosial dan tingginya laju pertumbuhan penduduk pendatang yang terkotak-kotak dalam blokblok perumahan eksklusif. Informasi yang tersebar melalui media sosial, terutama informasi-informasi keagamaan eksklusif dan formal, menjadi tantangan karena mengajak individu-individu beragama untuk tidak berinteraksi dengan umat agama lain. Persebarannya yang tersembunyi dalam ruang privat namun masif sulit dikendalikan jika tidak ada upaya dari berbagai pihak untuk memberikan pemahaman keagamaan yang jernih dan inklusif. Blok-blok perumahan yang kini banyak muncul di wilayah Kampung Sawah juga telah menciptakan masyarakat yang tersegregasi ke dalam kelompokkelompok eksklusif. Perumahan-perumahan dengan model seperti menjauhkan setiap penghuninya dari interaksi dengan penduduk setempat yang sudah lebih dahulu bermukim. Akibatnya, pengenalan terhadap kearifan lokal wilayah setempat sulit dilakukan.

Kondisi damai di Kampung Sawah masih akan terus diuji, terutama dengan berbagai informasi yang disebar melalui media sosial dalam kurun lima tahun belakangan dan perkembangan penduduk yang kini terkotak dalam blok-blok perumahan eksklusif. Daya tahan menjaga kondisi damai yang sudah berlangsung lama tentu saja memerlukan peran serta berbagai elemen masyarakat dan area pelibatan warga menjadi penting untuk diperluas. Berdasarkan berbagai temuan dan analisis hasil penelitian di atas, penelitian ini merekomendasikan untuk melakukan konservasi terhadap berbagai kearifan lokal yang ada di Kampung Sawah. Konservasi yang dimaksud setidaknya dalam bentuk menuliskan sejarah Kampung Sawah, berbagai tradisi dan kearifan lokal Kampung Sawah, membuat silsilah keluarga yang ada di Kampung Sawah, dan berbagai kegiatan literasi untuk merawat memori kolektif warga Kampung Sawah.

Berbagai kegiatan yang melibatkan berbagai elemen warga Kampung Sawah juga mesti terus dilakukan. Pelibatan warga dalam kegiatan-kegiatan yang selama ini sudah berlangsung kemudian diperluas tidak hanya warga asli ataupun yang sudah lama menetap di Kampung Sawah. Namun juga melibatkan penduduk yang tinggal di perumahanperumahan yang baru terbangun di Kampung Sawah. Pelibatan mereka bisa dalam bentuk keikutsertaan dalam kepanitiaan perayaan hari besar keagamaan, pesta budaya dan kenegaraan, dan aktivitas keseharian lainnya.

\section{UCAPAN TERIMA KASIH}

Penulis mengucapkan terima kasih yang setulusnya kepada berbagai pihak yang telah membantu terwujudnya penelitian ini. Terima kasih penulis sampaikan kepada Balai Litbang Agama Jakarta yang telah memberikan kepercayaan untuk melaksanakan tugas penelitian ini. Kepada Bapak Ahmad Syafii Mufid juga kami sampaikan terima kasih atas berbagai kritik dan saran selama proses penelitian dan penulisan hasil penelitian ini. Tak lupa terima kasih tulus penulis sampaikan kepada Pak KH. Rahmadin Afif, Pak Jacobus Napiun, Pak Mihardja Rikin, Pak Sholehudin Malik, dan berbagai elemen masyarakat di Kampung Sawah atas segala bantuan selama penelitian ini berlangsung.

\section{DAFTAR PUSTAKA}

Asikin, Naimah B. 2013. Studi Mobilitas Sosial Keluarga Betawi; Perubahan Status Kepemilikan Tanah Alih Generasi Keluarga Betawi di Pulo Gebang Kecamatan Cakung Jakarta Timur. Jurnal Insani, Nomor 15, Desember 2013; 28-44.

Aziz, Abdul. 2002. Islam dan Masyarakat Betawi. Jakarta; Logos Wacana Ilmu. 
Bagir, ZA., Ahnaf, MI., Tahun, M., Asyhari, B. 2013. Laporan Tahunan Kehidupan Beragama di Indonesia 2012. Yogyakarta; Program Studi dan Lintas Budaya (Center for Religious and Cross-Cultural Studies).

Halili, Naipospos, BT. 2015. Dari Stagnasi Menjemput Harapan Baru; Kondisi Kebebasan Beragama/Berkeyakinan di Indonesia 2014. Jakarta; Pustaka Masyarakat Setara.

Hanifan, L.J. 1916. The Rural School Community Center. The Annuals of the American Academy of Political and Social Science. Vol. 67, New Possibilities in Education (Sep., 1916), pp. 130-138.

Hayat, Bahrul. 2012. Mengelola Kemajemukan Umat Beragama. Jakarta; PT. Saadah Cipta Mandiri.

Human Right Watch (HRW). 2013. Atas Nama Agama; Pelanggaran terhadap Minoritas Agama di Indonesia. USA; Human Right Watch.

Jamaludin, AN. 2015. Sistem Kekerabatan Masyarakat Kampung Sawah di Kota Bekasi. Jurnal El-Harakah Volume 17 Nomor 2 Tahun 2015; 259-274.

Komnas HAM. 2016. Laporan Tahunan Kebebasan Beragama dan Berkeyakinan 2016. Jakarta; Komisi Nasional HAM Republik Indonesia.

Mahadi, Ujang. 2013. Membangun Kerukunan Umat Masyarakat Beda Agama Melalui Interaksi dan Komunikasi Harmoni di Desa Talang Benuang Provinsi Bengkulu. Jurnal Kajian Komunikasi, Volume 1 Nomor 1, Juni 2013; 51-58.

Mainarno, Eko A. 2011. Manusia dalam Kebudayaan dan Masyarakat. Jakarta; Salemba Humanika.

Panggabean, SR., Alam, RH., Fauzi, IA. 2010. The Patterns of Religious Conflict in Indonesia (1990-2008). Studia Islamika; Indonesian Journal for Islamic Studies. Volume 17 Number 2, 2010; 233-298.

Praptanto, Aloisius Eko. 2011. Sepangkeng Kisah Gereja Katolik Kampung Sawah. Bekasi; Seksi Komunikasi Sosial Paroki Santo Servatius.
Puslitbang Kehidupan Keagamaan. 2014. Pedoman Penanganan Aliran dan Gerakan Keagamaan Bermasalah di Indonesia (cet. ke-3). Jakarta; Puslitbang Kehidupan Keagamaan.

Salahudin, Marwan. 2008. Mengenal Kearifan Lokal di Klepu-Ponorogo; Praktik Hubungan Sosial Lintas Agama dan Mekanisme Pencegahan Konflik. Dalam Agama dan Kearifan Lokal dalam Tantangan Global (ed. Irwan Abdullah, Ibnu Mujib, M. Iqbal Ahnaf). Yogyakarta; Sekolah Pascasarjana UGM dan Pustaka Pelajar.

Setara Institute. 2017. Bersama Membangun Kota Toleran; Data Dasar Pemajuan Toleransi dan Perdamaian di 10 Kota. Jakarta; Pustaka Masyarakat Setara.

Siisiäinen, Martti. 2000. Two Concepts of Social Capital: Bourdieu vs. Putnam. Paper presented at ISTR Fourth International Conference "The Third Sector; For What and for Whom?" Trinity College, Dublin, Ireland, July 58, 2000.

Syahra, Rusydi. 2003. Modal Sosial; Konsep dan Aplikasi. Jurnal Masyarakat dan Budaya. Volume 5 No. 1 Tahun 2003. Hal. 1-22

Taormina, RJ., Kuok, AHC., Wei, W. 2012. Social Capital as Dehumanizing Terminology. Advances in Applied Sociology, 2012. Vol.2, No.2, 143-148. http://dx.doi.org/10.4236/aasoci.2012.2 2019.

Varshney, Ashutosh. 2001. Ethnic Conflict and Civil Society; India and Beyond. World Politics, Number 53, April 2001; 362-398.

Varshney, Ashutosh. 2009. Konflik Etnis dan Peran Masyarakat Sipil; Pengalaman India (terj. Siti Aisyah, Ayu Diasti, \& Sri Murniati). Jakarta; Balai Litbang Agama Jakarta.

Varshney, A., Panggabean, R., Tadjoedin, M.Z. 2004. Patterns of Conflict Violence in Indonesia (1990-2003). Jakarta; United Nations Support Facility for Indonesian Recovery (UNSFIR). 
Wahid Foundation. 2016. Laporan Tahuan

Kebebasan Beragama Berkeyakinan $(K B B)$ di Indonesia tahun 2016 (Ringkasan Eksekutif). Jakarta; Wahid Foundation.

\section{Internet}

Firdaus, Andi. 2016. Kemendagri: Kampung Sawah Bekasi Percontohan Kerukunan Beragama. Didapat dari https://www.antaranews.com/berita/ 576259/kemendagri-kampungsawah-bekasi-percontohankerukunan-beragama, pada 6 Pebruari 2018.

Pusat Kerukunan Umat Beragama. 2017. Kemenag Akan Ciptakan Desa Percontohan Sadar Kerukunan. Didapat dari

https://pkub.kemenag.go.id/berita/4 73900/kemenag-akan-ciptakandesa-percontohan-sadar-kerukunan, pada 6 Pebruari 2018.

Setara Institute. 2018. Memimpin Promosi Toleransi; Kondisi Kebebasan Beragama/Berkeyakinan dan Minoritas Keagamaan di Indonesia 2017 (Ringkasan Eksekutif). Didapat dari http://setara-institute.org/memimpinpromosi-toleransi/, pada 6 Pebruari 2018.

Wardah, Fathiyah. 2017. Kerukunan Umat Beragama di Kampung Sawah. Didapat dari

https://www.voaindonesia.com/a/ke rukunan-umat-beragama-dikampung-sawah-/4180694.html, pada 6 Pebruari 2018.

Yulianto, Agus. 2017. Wahid Foundation Inisasi Pembentukan Kampung Damai. Didapat dari http://khazanah.republika.co.id/berit a/dunia-islam/islamnusantara/17/09/08/ovyxsk-wahidfoundation-inisiasi-pembentukankampung-damai, pada 6 Peburari 2018. 
